\title{
ArcheoSciences
}

Revue d'archéométrie

$40 \mid 2016$

Varia

\section{Beads excavated from Antsiraka Boira necropolis (Mayotte Island, 12th-13th centuries)}

Colouring agents and glass matrix composition comparison with contemporary Southern Africa sites

Agents colorants et matrices vitreuses des perles de la nécropole d'Antsiraka Boira (Île de Mayotte, XIIe-XIIIe siècles). Comparaison avec les sites contemporains d'Afrique Australe

Noémi Fischbach, Anh-Tu Ngo, Philippe Colomban and Martial Pauly

\section{OpenEdition}

Electronic version

URL: https://journals.openedition.org/archeosciences/4774

DOI: 10.4000/archeosciences.4774

ISBN: 978-2-7535-5384-2

ISSN: 2104-3728

Publisher

Presses universitaires de Rennes

Printed version

Date of publication: 30 December 2016

Number of pages: 83-102

ISBN: $978-2-7535-5382-8$

ISSN: $1960-1360$

Electronic reference

Noémi Fischbach, Anh-Tu Ngo, Philippe Colomban and Martial Pauly, "Beads excavated from Antsiraka Boira necropolis (Mayotte Island, 12th-13th centuries)", ArcheoSciences [Online], 40 | 2016, Online since 30 December 2018, connection on 25 February 2022. URL: http://

journals.openedition.org/archeosciences/4774 ; DOI: https://doi.org/10.4000/archeosciences.4774 


\title{
Beads Excavated from Antsiraka Boira Necropolis (Mayotte Island, $12^{\text {th }}-13^{\text {th }}$ centuries) Colouring Agents and Glass Matrix Composition Comparison with Contemporary Southern Africa Sites
}

\author{
Agents colorants et matrices vitreuses des perles de la nécropole d'Antsiraka Boira \\ (Ille de Mayotte, XII ${ }^{e}$-XIII siècles) \\ Comparaison avec les sites contemporains d'Afrique Australe
}

Noémi Fischbach ${ }^{a}$, Anh-Tu NGo ${ }^{a}$, Philippe Colomban ${ }^{a}$ et Martial Pauly

\begin{abstract}
About hundred out of three hundred colored beads excavated from the necropolis of Antsiraka Boira (AB), in Mayotte Island (12$13^{\text {th }}$ c.) were classified according to Wood's morphological criteria and studied with a portable Raman spectrometer $(532 \mathrm{~nm})$. Based on the recorded spectra, 22 beads were identified as representative and further analyzed in the laboratory with High-Resolution Raman spectrometers, using wavelengths of 458, 633 and 785nm. Additional SEM-EDS analysis was carried out on the surface and, sometimes, the bead cross-section. It turns out that white beads are made of aragonite and that almost all other beads have a soda glass matrix. Pyrochlore (yellow), amber/“Fe-S” (black), manganese oxide (black), copper metal nanoparticles (red), and $\mathrm{Cu}^{2+}$ ions (turquoise) chromophores were identified. Some red, yellow, black and turquoise beads also show the signature of chromium-doped tin sphene that could therefore be used as a marker. Most beads from the AB site can be classified as "Indo-Pacific", revealing a similarity with the contemporary South African site of K2 (close to Mapungubwe). However, some red and black beads are similar to molten ceramic beads from the Vohemar Islamic necropolis (13-17 ${ }^{\text {th }}$ century AD, Madagascar Island). The on-site Raman analysis appears sufficient for the identification of chromophores and glass types.
\end{abstract}

Résumé : Un ensemble d'une centaine de perles de la nécropole d'Antsiraka Boira (AB), Mayotte (XII-XIII siècles), considérées comme représentatives d'un lot de -300, a été classé selon le système morphologique de Wood et analysé par spectroscopie Raman portable (532 nm). 22 perles représentatives ont été analysées par Raman avec différentes excitations laser (458,633 et $785 \mathrm{~nm}$ ) et SEM-EDS en surface, ou pour certaines sur section. Les chromophores ont été identifiés : pyrochlore (jaune), ambre/Fe-S (noir), oxyde de manganèse (noir), Cu metal nanoparticules (rouge) et Cü ${ }^{2+}$ ions (turquoise). Les perles blanches sont en aragonite $\left(\mathrm{CaCO}_{3}\right)$. Quelques perles rouges, jaunes, noires et une perle turquoise contiennent aussi le chromophore Cr-Sn sphène. Sa signature Raman, inattendue, pourra servir de marqueur. La quasi-totalité des matrices vitreuses sont sodiques. La comparaison des perles d'AB avec celles des sites de Mapungubwe/K2 (Afrique du Sud), met en évidence l'homogénéité du corpus comme pour K2, site contemporain de Antsiraka Boira et aussi classé "Indo-Pacifique ". Certaines perles rouges et noires, sont plus proches d'une céramique fondue que d'un verre, à l'instar de perles de Vohémar (XIIT-XVII siècle, Madagascar). L'analyse au spectromètre Raman portable apparait suffisante pour identifier chromophores et types de verre.

Keywords: Mayotte, glass, beads, Indian Ocean, pigment, composition.

Mots clés : Mayotte, verre, perle, océan Indien, pigment, composition.

a Sorbonne Universités, UPMC Université Paris 6-CNRS, IP2CT, UMR 8233, MONARIS, 75005 PARIS, France. (noemi.fischbach@gmail.com) (anh-tu.ngo@courriel.upmc.fr) (philippe.colomban@upmc.fr)

b INALCO-CROIMA, 75007 PARIS, France (celmartial@hotmail.com) 


\section{INTRODUCTION}

At the beginning of the first millenium A.D., the Indian Ocean became a region of long-distance trade between the Middle East, China, India, South Asia and Africa. Over the centuries, mostly thanks to monsoons, it was organized into a space around which the first World Trade system was built (Beaujard, 2009; Beaujard, 2012). Indeed, by its geographical situation, the Indian Ocean is subject to the phenomenon of monsoon winds whose seasonal fluctuation determined navigation and commerce in the area (Nativel \& Rajaonah, 2007). At the time, it was possible to travel from Asia-to-Africa and up to the entrance of the Mozambique Channel in a single season; on the other side, trade to ports located more to the South needed a waiting period for the next cycle. Livestock, raw or processed materials like ivory, pearls, wood, metals, pottery and glass beads have travelled over the Indian Ocean trade routes. Glass beads, which were used as a currency, attest to international trade by their presence. They are among the most abundant objects found at excavations due to their very good preservation, even in the humid tropics.

Identifying the source of excavated beads is useful to understand the history of exchanges and the building of trade routes. Beads are present from the $7^{\text {th }}$ and the $20^{\text {th }}$ century and over this period morphological and compositional changes take place. These modifications can be associated to the onset of specific periods of production or to some geographical area (Dussubieux et al., 2008; Prinsloo \& Colomban, 2008; Robertshaw et al., 2006; Robertshaw et al., 2009; Robertshaw et al., 2010; Tournié et al., 2011; Wood, 2005; Wood, 2011; Wood et al., 2009; Denbow et al., 2015). International trade to South/ East Africa through the Indian Ocean during the Iron Age ( $600-1750$ A.D.) received considerable attention (Beaujard, 2009; Beaujard, 2012). The first study of glass beads discovered in South Africa followed the excavation in 1930 of two large sites in the Limpopo valley, namely Mapungubwe and K2. The chronology of these sites has long been debated; the abundance and the variety of beads found there naturally led to use them as markers. To this end, numerous studies attempted to classify beads according to morphological criteria (Beck, 1937; Van Riet Low, 1955; Schofield 1958; Gardner, 1963), elemental composition or traces of rare earths (REE) (Davidson, 1972; Davidson, 1974). Recently, Wood proposed a classification system for southern African beads from the precolonial period (700-1600 A.D.) (Wood, 2005; Wood, 2011; Wood et al., 2009). This classification, based on morpho- logical and technological characteristics - which implies subjectivity - defines seven different sets of beads, each of them being related to a particular period determined by radiocarbon dating $(\mathrm{RC})$ of the site from which they were excavated. By definition, this classification requires reliable radiocarbon dating of the associated sites. However, the 1970s' RC dating of Mapungubwe and K2 sites was heavily influenced by the ideological context of the time, and questioned by the recent identification of chrono-technological markers (Tournié et al., 2011), which were more in line with the early work by Gardner (1963). To improve this ranking system, elemental analyzes were conducted by LA-ICP-MS (Robertshaw et al., 2006; Robertshaw et al., 2009; Robertshaw et al., 2010) so to provide information on glass production techniques and origins, including colouring elements (Robertshaw et al., 2010). Additionally, trace elements usually found in African glass beads compared to those found in India, Sri Lanka and East/South African Coast ones have enabled more accurate time correlations (Chaisuwan, 2011; Dussubieux et al., 2008; Dussubieux et al., 2010; Robertshaw et al., 2006; Robertshaw et al. 2009).

Meanwhile, Raman spectroscopy has emerged as the most effective non-invasive method to identify chromophores, pigments and opacifiers in glasses and enamels (Bonneau et al., 2013; Colomban et al., 2001; Colomban \& Treppoz, 2001; Colomban et al., 2003; Ricciardi et al., 2009a; Ricciardi et al., 2009b; Prinsloo \& Colomban, 2008; Prinsloo et al., 2011; Tournié et al., 2010, Tournié et al., 2011; Welter et al., 2007) as well as the types of glass matrix (Colomban et al., 2006a; Colomban et al., 2006b). This approach is widely used now (Baert et al., 2011; Caggiani et al., 2014; de Ferri et al., 2012; Gedzevičiūtè et al., 2009; Koleini et al., 2016a; Prinsloo et al., 2011; Prinsloo et al., 2012). Some pigments and chromophores are unique technological chrono-markers. In addition to confirming the first chronology of the site established by Gardner, Raman analysis of Mapungubwe and K2's beads also confirmed the links that Africa had with the outside world thanks to the finding of: Indo-Asian black beads with Fe-S chromophore (Prinsloo \& Colomban, 2008); Lapis Lazuli colored blue beads typical of Islamic glasses between the $13^{\text {th }}$ and $15^{\text {th }}$ century (Caggiani et al., 2014; Prinsloo et al., 2011). These studies concern the major sites of the upper valley of the Limpopo River (Mapungubwe / K2) but other sites were studied: such as further along the Limpopo in South Africa (Koleini et al., 2016c), Botswana (Koleini et al., 2016a), and Zimbabwe sites, rivals of Mapungubwe and $\mathrm{K} 2$ ones in a later date (Koleini et al., 2016b) and on the material collected in the early $20^{\text {th }}$ century at Vohemar, a harbor occupied by Malagasy Islamized and in close rela- 
tionship with the Swahili world in northeastern Madagascar (Colomban \& Simsek, 2014).

This work concerns a selection of beads from the necropolis of Antsiraka Boira, Mayotte, one of the four islands in the Comoros Archipelago in the Indian Ocean. Mayotte is located at the northern entrance of the Mozambique Channel between the island of Madagascar and East Africa, and because of its position at the end of the road of Monsoon (going south imposes waiting for the next cycle of Monsoon) an important step in trade with southern Africa. Commercial networks with the other islands of the channel, Madagascar and Africa, are attested from the $8^{\text {th }}$ to the $13^{\text {th }}$ century (Beaujard, 2009; Beaujard, 2012; Pauly, 2014). Because of its position at the entrance of the Mozambique Channel, many Islamic traders chose to establish trading posts in the island of Mayotte ever since the $9^{\text {th }}$ century, which led to the introduction of the Swahili culture and the Muslim religion into the Island. The spread of Islam across the Indian Ocean is closely related to commercial networks linking Africa to the Middle East (Pauly, 2014). Recent excavations (2012-2014) have uncovered a medieval necropolis dated to around 1100-1250 with a well-defined stratigraphy (Pauly, 2014). Nearly two thirds of the excavated tombs contained glass beads, for a total of about ten thousand. These burials revealed a phase of synergy between Muslim funeral rituals and pre-Islamic rituals. With the exception of the Islamic Necropolis of Vohemar $\left(13^{\text {th }}\right.$ $17^{\text {th }}$ centuries), northeast of Madagascar, Antsiraka Boira is the sole provider of bead adornments found in funerary context (table 1, the concordance between the labels used in this work and those of the funerary excavation). About a hundred beads of the necropolis of Antsiraka Boira, representative of 331 beads chosen on morphological criteria (shape, color, size and type of apparent production technology) were first Raman analyzed with a portable $532 \mathrm{~nm}$ set-up that can be used on site (Colomban, 2013). Twenty- two of them (Figure 1) were selected based on their Raman signature representative of the different groups for further analysis with a laboratory instrument. Indeed, this work also aims at establishing an appropriate on site selection methodology, in order to limit the number of objects requiring additional laboratory analysis.

\section{Materials AND METHODS}

\section{Beads}

Figure 1 shows the 22 selected beads and the first classification according to the morphological criteria defined by Wood (Wood, 2005, Wood, 2011, Wood, 2012). The beads used in the discriminating criteria can be linked to a series associated with a chronological period. According to visual criteria, almost all beads belong to the Indo-Pacific category, divided into three series: K2-IP, East Coast (EC-IP), and Khami-IP (Figure 1 and Table 2). All the beads are monochrome, but of different colors: black (n), blue / turquoise (b), yellow (y), and red-brown (r). Most of the selected beads were made by drawing a glass gob and have a cylindrical shape. Two beads were made by winding in a more or less spherical fashion (10-n and 22-r). Beads 18-y and 17-b do not exhibit morphological criteria suitable to assign them to a particular series and bead \#11 is not made of glass.

\section{Analyses}

A small spot on the bead surface was cleaned with a fine dry abrasive paper in order to remove surface residues and any loose layers of corrosion products, to obtain the best Raman signature on the uncorroded matrix. MicroRaman analyzes were performed with 4 spectrometers: a portable HE 532 (HORIBA Jobin Yvon Scientific), a fixed HR 800 (HORIBA Jobin Yvon Scientific), a transportable

\begin{tabular}{|c|c|c|c|c|c|c|c|c|}
\hline Label & 1 & 2 & 3 & 4 & 5 & 6 & 7 & 8 \\
\hline Arch. & SP10PRp1 & SP10PRp4 & SP02PJp3 & SP02PJp2 & SP15PNp22 & SP15PNp1 & SP30PNICp1 & SP09PNp11 \\
\hline Label & 9 & 10 & 11 & 12 & 13 & 14 & 15 & 16 \\
\hline Arch. & SP30PNICp3 & SP01PNp2 & SP34PCp26 & SP09PNp2 & SP02PNp2 & SP10PRp5 & SP10PTp2 & SP39PBp \\
\hline Label & 17 & 18 & 19 & 20 & 21 & 22 & & \\
\hline Arch. & SP24PTp4 & SP15PJc6 & SP09PTp2 & SP34PRp2 & SP30PNICp2 & SP39PRp3 & & \\
\hline
\end{tabular}

Table 1: Correspondence between archaeological labels (sepulture number (SP), bead number (P) color (red, R; ...), loin cloth (p), necklace (c).

Tableau 1: Correspondance entre les numéros d'inventaire archéologiques (numéro de sépulture (SP), de perle (P); symboles : couleur (rouge, $R ; . .$.$) , pagne ( p)$, collier (c). 

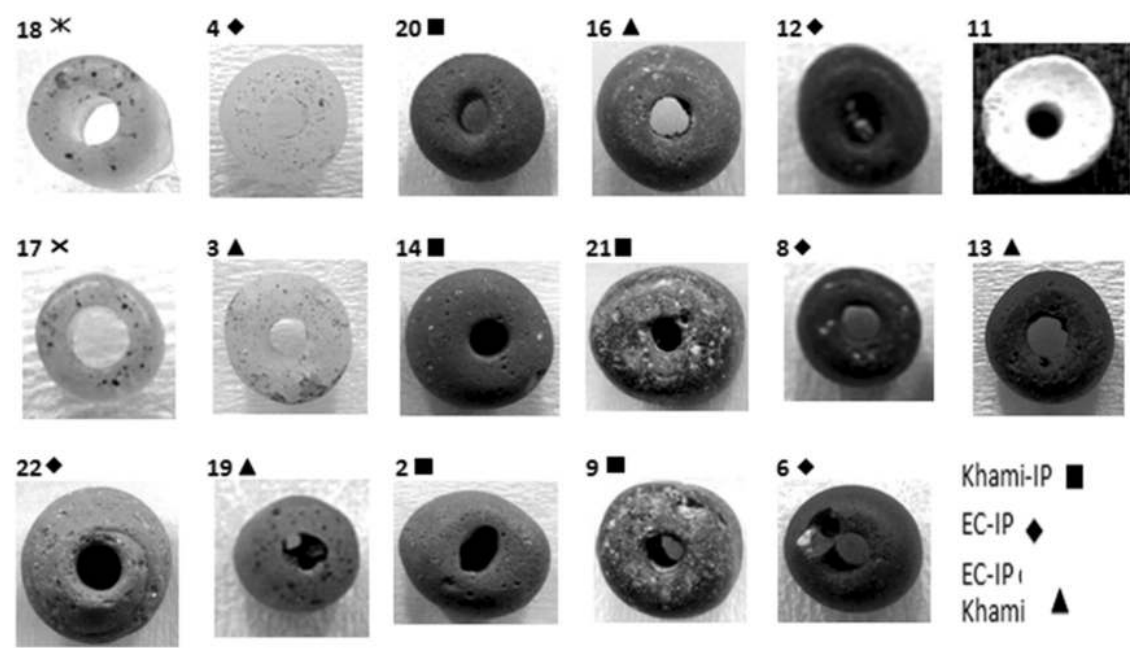

Khami-IP

EC-IP

EC-IP,

Khami
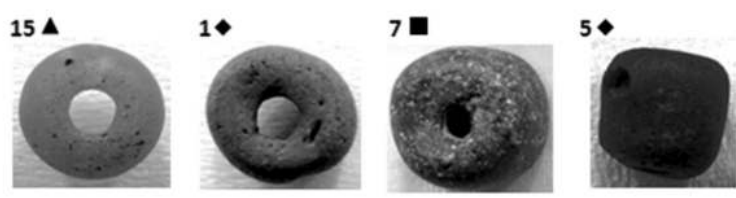

Figure 1: (See colour plate X) Representative glass beads of Antsiraka Boira site (Mayotte Island), selection based on their color (blue, red, yellow and black), their method of manufacture (drawn, wound) and their state of transparency (translucent, translucent-opaque, opaque). The classification series (Khami-IP-; EC-IP; K2-IP) according to the morphological criteria defined by M. Wood is indicated.

Figure 1: (Voir planche couleur X) Sélection de perles de verres représentatives de la nécropole d'Antsiraka Boira (île de Mayotte), en fonction de la couleur (bleu, rouge, jaune ou noir), la méthode de fabrication manufacture (étirage ou enroulage) et du degré de transparence (translucide, opaque ou intermédiaire). La classification morphologique selon Wood est aussi donnée (IP-Khami; EC-IP; K2).

\begin{tabular}{|c|c|c|c|c|c|}
\hline Bead label & Color & $\begin{array}{c}\text { Diameter } \\
(\mathrm{mm})\end{array}$ & $\begin{array}{c}\text { Length } \\
(\mathrm{mm})\end{array}$ & Criteria & Size, shape \\
\hline $2,7,9,14,20,21$ & Red - brown, black & $5-7.1$ & $3.5-6.5$ & Khami - IP \\
\hline $\begin{array}{c}1,4,5,6,8,10, \\
12,22\end{array}$ & $\begin{array}{c}\text { Red - brown, } \\
\text { black, yellow, orange }\end{array}$ & $2.5-5$ & $1.5-5$ & EC - IP \\
\hline $3,15,16,19,13$ & $\begin{array}{c}\text { Yellow, turquoise, } \\
\text { black }\end{array}$ & $3-5.2$ & $2-4.1$ & EC - IP / Khami \\
\hline 17,18 & Turquoise, yellow & $2,2.5$ & Size, shape, & K2 ? \\
\hline 11 & White & 4.5 & 3.5 & $/$ \\
\hline
\end{tabular}

Table 2: Classification of Mayotte beads, according to the morphological criteria presented by (Wood, 2005, 2009, 2011), correspondence with archaeological names are specified in Table 1.

Tableau 2: Classification des perles de Mayotte selon les critères morphologiques de Wood (Wood, 2005, 2009, 2011), voire Table 1 pour les symboles.

Infinity (Dilor-HORIBA Scientific) and a transportable SENTERRA Scope III (Bruker Optics). All are coupled with long working distance microscope objectives, magnification of $\times 10, \times 50$ and $\times 100$ that lead to 100,500 and 1,000 magnifications. The use of different optics allows controlling the glass heterogeneity. For each record, Raman spectrometers were used with an acquisition time of 30 to 450 seconds, and if needed, several accumulations to improve the signal / noise ratio and clear the cosmic photons. The hundred beads were analyzed with the portable spectrometer (under excitation of $-2-5 \mathrm{~mW}$ for black beads because of the high absorption, and $-10-20 \mathrm{~mW}$ for colored beads). Those whose spectrum recorded with HE532 portable instrument was of low quality (yellow and blue) were also measured with the HR 800 spectrometer under laser excitation of $458 \mathrm{~nm}$, blue excitation being well suited for the analysis of glasses. Infinity $(633 \mathrm{~nm}, 35 \mathrm{~mW})$ and SENTERRA (785 nm, 10-50 mW) spectrometers were used on black beads to evaluate and / or to overcome the resonance effect of the Fe-S chromophore.

Despite the lower spectral resolution of the portable instrument and the limited access to low wavenumber range $\left(<100 \mathrm{~cm}^{-1}\right)$, most Raman spectra obtained with the portable apparatus are significant and exploitable (Figure 2a) and 
Figure 2: Examples of Raman spectra recorded using different spectrometers: a) portable $(532 \mathrm{~nm})$. b) fixed (HR800, $458 \mathrm{~nm}$; Infinity 532/633, and Senterra, $785 \mathrm{~nm})$. Bead labels are given according to Fig. 1 (Colours; n: black, r: red, y: yellow and b: blue/turquoise.

Figure 2 : Exemples de spectres Raman obtenus avec différent spectromètres: a) portable $(532 \mathrm{~nm})$ - b) fixe (HR800 458 nm; Infinity, 532/633 ; Senterra, 785 nm). Les symboles de la Fig. 1 sont utilisés (Couleur: n: noir, r: rouge, y: jaune \& b; bleu/turquoise.

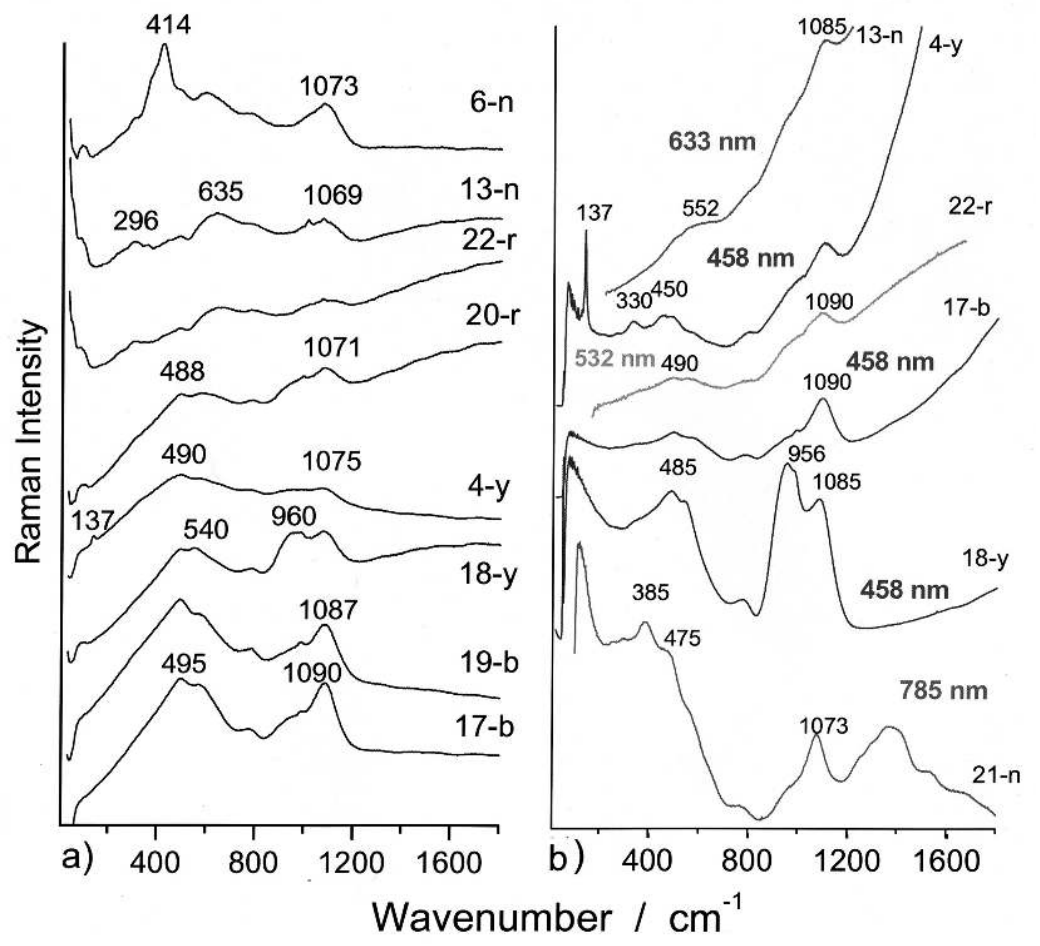

(pre)resonance, change of the excitation wavelength significantly modifies the respective intensities of the chromophore and its matrix allowing a better observation of one or the other (Faurel et al., 2003).

\section{Scanning electron microscopy (SEM-EDS)}

Elemental analyzes (by oxide weight \%, Table 3) of Boira Antsiraka beads were performed with a SEM (JEOL JSM-5510LV) equipped with an EDS detector (Energy Dispersive Scattering). A $30 \mathrm{kV}$ acceleration voltage was used with a working distance of $20 \mathrm{~mm}$. Fixed to a metal support with carbon adhesive recoveries to best remove the charges created by electron irradiation, beads were examined without preparation. The validity of the measurements was monitored by applying the same procedure to certified glass-reference samples "Corning Museum B, C and D" and American "National Bureau of Standard (NBS 620)", as usual (Vicenzi et al., 2002; Henderson et al., 2016). The error is below $1 \%$ for $\mathrm{SiO}_{2}, \mathrm{Na}_{2} \mathrm{O}$ and $\mathrm{CaO}$, and below $5 \%$ for the other oxides. For each bead, several qualitative and quantitative measurements were performed, first at low magnification (100x, overall analysis), then at high magnification (up to $3000 \mathrm{x}$ ) to assess the material heterogeneity. secondary phases, the characteristic Raman bands are narrow, intense and thus easily detectable (Figure 3). In case of 


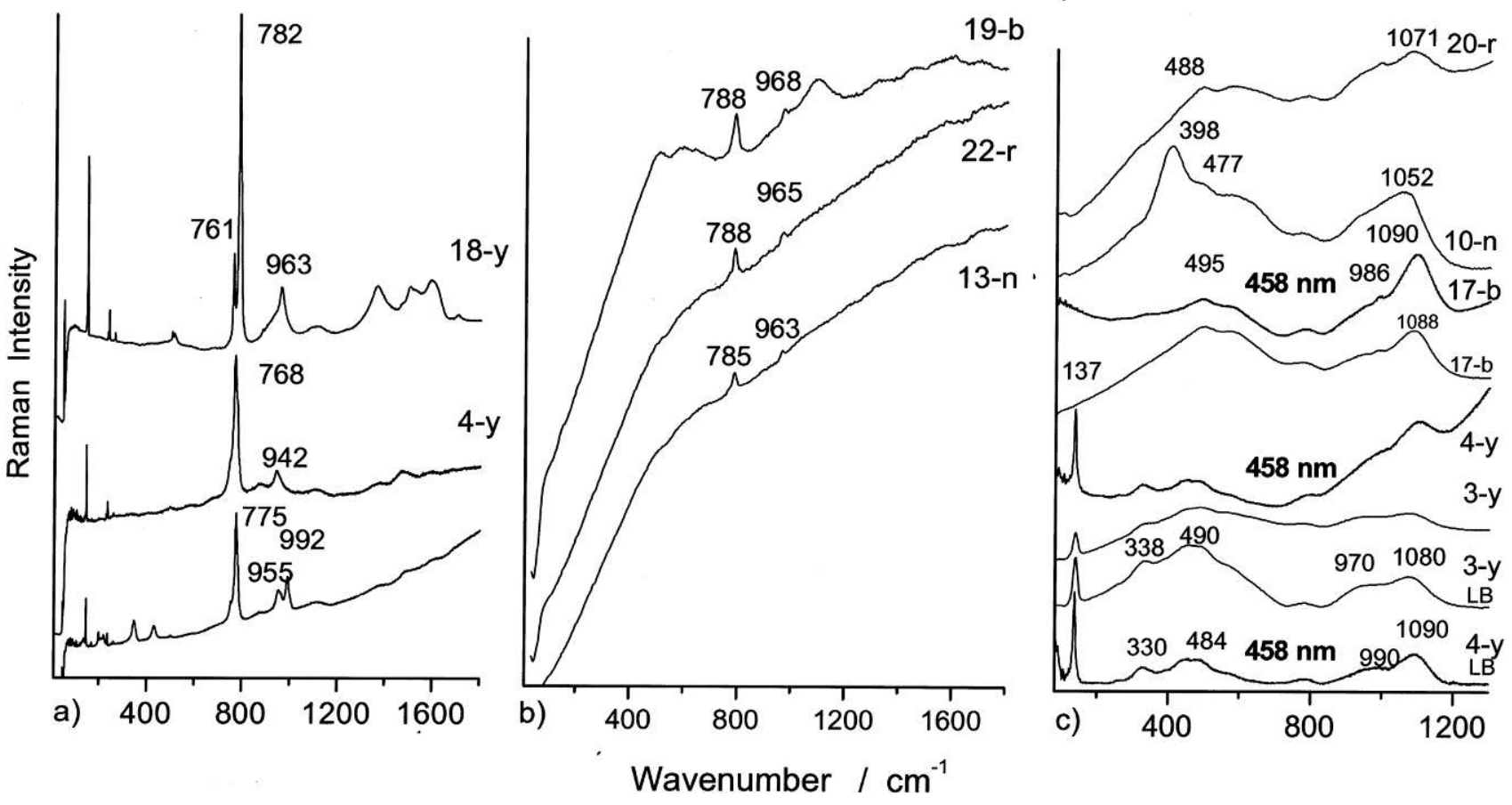

Figure 3: Raman spectra of the chromophore Cr-Sn / sphene recorded by a) the fixed HR800 instrument (458nm) and b) the portable HE532, (532nm); c) comparison of representative spectra recorded with 532 (not labelled) or 458 nm (labelled) excitation (LB: the baseline has been subtracted).

Figure 3 : Spectres Raman du chromophore Cr-Sn sphène obtenus avec a) le spectromètre fixe HR800 (458nm) et b) le spectromètre portable HE532, (532 nm). c) Comparaison de spectres typiques obtenus avec les excitations à 532 or $458 \mathrm{~nm}$ (LB: une ligne de base a été soustraite).

\section{Results}

\section{Identification of the chromophores}

Raman spectroscopy has proven to be particularly effective in identifying colouring matters, except for the chromophore ions $\left(\mathrm{Cu}^{2+}, \mathrm{Fe}^{2+}, \mathrm{Fe}^{3+}, \mathrm{Co}^{2+}, \mathrm{Mn}^{\mathrm{n}+}\right.$, etc. $)$ that are "simply" dissolved in the glass matrix, as their presence do not have a strong influence on the matrix spectrum (Colomban et al., 2001). The Raman signature of well crystallized compounds usually consists of narrow peaks that are easy to detect. This is the case of most pigments and opacifiers: highly crystalline compounds that are stable in the molten glass or have precipitated on cooling. Additionally, when the excitation wavelength (almost) corresponds to the coloration, the (pre-)resonance character of the spectrum improves its detectivity and small amounts of chromophores $(<\% \mathrm{wt})$ give intense spectra.

\section{Yellow beads}

For yellow beads 3-y and 4-y (Figures 2, $3 \& 4$ ) the Raman spectrum is characteristic of a pyrochlore pigment, a complex solid solution $\mathrm{PbSb}_{2-\mathrm{x}} \mathrm{Sn}_{\mathrm{x}} \mathrm{Z}_{\mathrm{y}} \mathrm{O}_{7-\delta}$, also called Naples Yellow. The spectrum of this pigment is characterized by bands at about 135, 330 and $453 \mathrm{~cm}^{-1}$ (Kirmizi et al. 2010; Rosi et al., 2009; Sakellariou et al., 2004). The exact position of these bands and the relative intensities vary according to both the composition (including the $\mathrm{Sn} / \mathrm{Sb}$ ratio and the non-stoichiometry in oxygen resulting from oxidation state of the metal elements) and heat treatments, thus modifying the non-stoichiometry and order (Pereira et al., 2009). It is often difficult for determining the non-stoichiometry (Naples Yellow Type I [Sb-rich, usually recognized from its $510 \mathrm{~cm}^{-1}$ band] or II [Sn-rich with characteristic $450 \mathrm{~cm}^{-1}$ component]) only on the basis of the Raman spectrum. The yellow bead 18-y, does not exhibit the pyrochlore signature. The absence of lead is confirmed by SEM-EDS analysis, and high iron content (1.9 wt oxide \%) rather indicates a colour due to $\mathrm{Fe}^{3+}$ ions, a known technique for enamels but rare for glass objects. A resonant spectrum $\left(761-775 \mathrm{~cm}^{-1}\right.$ and $942-963 \mathrm{~cm}^{-1}$ peaks followed by harmonics / combinations, Figure 4) characteristic of a sphene (malayite) containing tin doped with chromium and used for the pink to brown porcelain enamel since the $19^{\text {th }}$ century (Faurel et al., 2003), 


\begin{tabular}{|c|c|c|c|c|c|c|c|c|c|c|c|c|}
\hline Label & $\% \mathrm{SiO}_{2}$ & $\% \mathrm{Al}_{2} \mathrm{O}_{3}$ & $\% \mathrm{CaO}$ & $\% \mathrm{Na}_{2} \mathrm{O}$ & $\% \mathrm{~K}_{2} \mathrm{O}$ & $\Sigma$ Flux & Total & & $\% \mathrm{CaO}$ & $\% \mathrm{Na}_{2} \mathrm{O}$ & $\% \mathrm{~K}_{2} \mathrm{O}$ & Total \\
\hline 1 & 71.3 & 6.6 & 2.1 & 17.9 & 2.1 & 22.1 & 100.0 & & 9.5 & 81.0 & 9.5 & 100.0 \\
\hline 2 & 71.4 & 8.25 & 1.4 & 17.3 & 1.6 & 20.3 & 100.0 & & 6.9 & 85.2 & 7.9 & 100.0 \\
\hline 3 & 71.6 & 9.5 & 3.0 & 13.7 & 2.1 & 18.8 & 99.9 & & 15.8 & 73.0 & 11.2 & 100.0 \\
\hline 4 & 73 & 7.4 & 2.5 & 15.5 & 1.6 & 19.6 & 100.0 & & 12.8 & 79.1 & 8.2 & 100.0 \\
\hline 5 & 70.8 & 7.8 & 2.4 & 16.5 & 2.4 & 21.3 & 99.9 & & 11.3 & 77.5 & 11.3 & 100.0 \\
\hline 6 & 70.9 & 7.6 & 2.3 & 16.7 & 2.5 & 21.5 & 100.0 & & 10.7 & 77.7 & 11.6 & 100.0 \\
\hline 7 & 74.5 & 10.7 & 1.5 & 11.8 & 1.4 & 14.7 & 99.9 & & 10.2 & 80.3 & 9.5 & 100.0 \\
\hline 8 & 76.5 & 5.3 & 1.3 & 14.9 & 2 & 18.2 & 100.0 & & 7.1 & 81.9 & 11.0 & 100.0 \\
\hline 9 & 77.2 & 8.8 & 2.2 & 9.8 & 2.0 & 14.0 & 100.0 & & 15.8 & 70.2 & 14.0 & 100.0 \\
\hline 10 & 70.1 & 8.3 & 2.4 & 18 & 1.2 & 21.6 & 100.0 & & 11.1 & 83.3 & 5.6 & 100.0 \\
\hline 12 & 71.9 & 8.2 & 1.9 & 15.8 & 2.2 & 19.9 & 100.0 & & 9.5 & 79.4 & 11.1 & 100.0 \\
\hline 13 & 69.7 & 6.9 & 3.1 & 17.4 & 2.8 & 23.3 & 99.9 & & 13.3 & 74.7 & 12.0 & 100.0 \\
\hline 14 & 72.1 & 8.2 & 2 & 16 & 1.6 & 19.6 & 99.9 & & 10.2 & 81.6 & 8.2 & 100.0 \\
\hline 15 & 70.5 & 6.1 & 2.1 & 19.3 & 2.1 & 23.5 & 100.1 & & 8.9 & 82.1 & 8.9 & 100.0 \\
\hline 16 & 73.9 & 8.6 & 1.8 & 13.4 & 2.3 & 17.5 & 100.0 & & 10.3 & 76.6 & 13.1 & 100.0 \\
\hline 17 & 67.4 & 13.3 & 3.1 & 14.1 & 2.0 & 19.2 & 99.9 & & 16.2 & 73.6 & 10.2 & 100.0 \\
\hline 18 & 72.5 & 6.4 & 2.5 & 16.7 & 1.8 & 21.0 & 99.9 & & 11.9 & 79.5 & 8.6 & 100.0 \\
\hline 19 & 72.5 & 8.8 & 1.6 & 15 & 2.1 & 18.7 & 100.0 & & 8.6 & 80.2 & 11.2 & 100.0 \\
\hline 20 & 70.9 & 7.9 & 1.4 & 18.3 & 1.5 & 21.2 & 100.0 & & 6.6 & 86.3 & 7.1 & 100.0 \\
\hline 21 & 75.6 & 7.9 & 1.6 & 13.7 & 1.2 & 16.5 & 100.0 & & 9.7 & 83.0 & 7.3 & 100.0 \\
\hline 22 & 73.1 & 5.9 & 2.2 & 17.2 & 1.6 & 21.0 & 100.0 & & 10.5 & 81.9 & 7.6 & 100.0 \\
\hline
\end{tabular}

Table 3: SEM-EDX oxide compositions of beads (wt\%) measued using 100x magnification on the surface. Only major oxides are considered. $\Sigma$ Flux $=\mathrm{CaO}+\mathrm{Na}_{2} \mathrm{O}+\mathrm{K}_{2} \mathrm{O}$.

Tableau 3: Compositions de surface (\% pondéral en oxyde) des perles mesurées par MEB-EDX pour un grossissement de 100. Seuls les éléments majeurs sont pris en compte. Fondants: $\Sigma$ Flux $=\mathrm{CaO}+\mathrm{Na}_{2} \mathrm{O}+\mathrm{K}_{2} \mathrm{O}$.

is obtained at points of the beads 18 and 4-y. The SEMEDS analysis confirms the presence of chromium (0.02$0.04 \mathrm{wt} \%)$ and tin (0.2-0.3 wt\%). The ratio between the two elements is consistent with this type of pigment. When this sphene pigment is combined with other chromophores, such as Naples yellow (bead 4-y) or the yellow iron (bead $18-y)$, it could only change the hue, not the colour. This very specific Raman signature can be used as a marker of bead production.

\section{Red beads}

Raman signatures vary according to the beads and the analysed spot (Figure 4a, spectrum 22-r and 1-r). Elemental analyses were able to detect the presence of copper $(0.04$ $0.2 \mathrm{wt} \%)$ and iron (0.4-0.8 wt\%) in all the red beads, in accordance with a red colouring obtained by dispersing $\mathrm{Cu}^{0}$ metallic copper nanoparticles in the glass matrix (Colomban, 2009; Colomban et al., 2009). This is consistent with the complexity of Raman signatures (Colomban \& Schreiber, 2005). The above mentioned Raman signature of the Cr-Sn chromophore was also identified for three beads, 2-r, 20-r and 22-r, with some variations as a function of the analysed spot (Figure 4a). Elemental analyses confirm the presence of tin (0.1-0.2 wt\%) and chromium traces (0.01-0.1 wt\%).

\section{Turquoise Beads}

No specific Raman signature was observed for turquoise beads (15-b, 17-b, 19-b) of Antsiraka Boira (e.g. Figure 2, the spectrum 17-b), in agreement with a dispersion of $\mathrm{Cu}^{2+}$ ion in an alkaline glass matrix (Eppler \& Eppler, 2000; Colomban et al., 2001). The SEM-EDS elemental analysis confirmed the presence of copper $(0.1-0.3 \%$ by weight of 


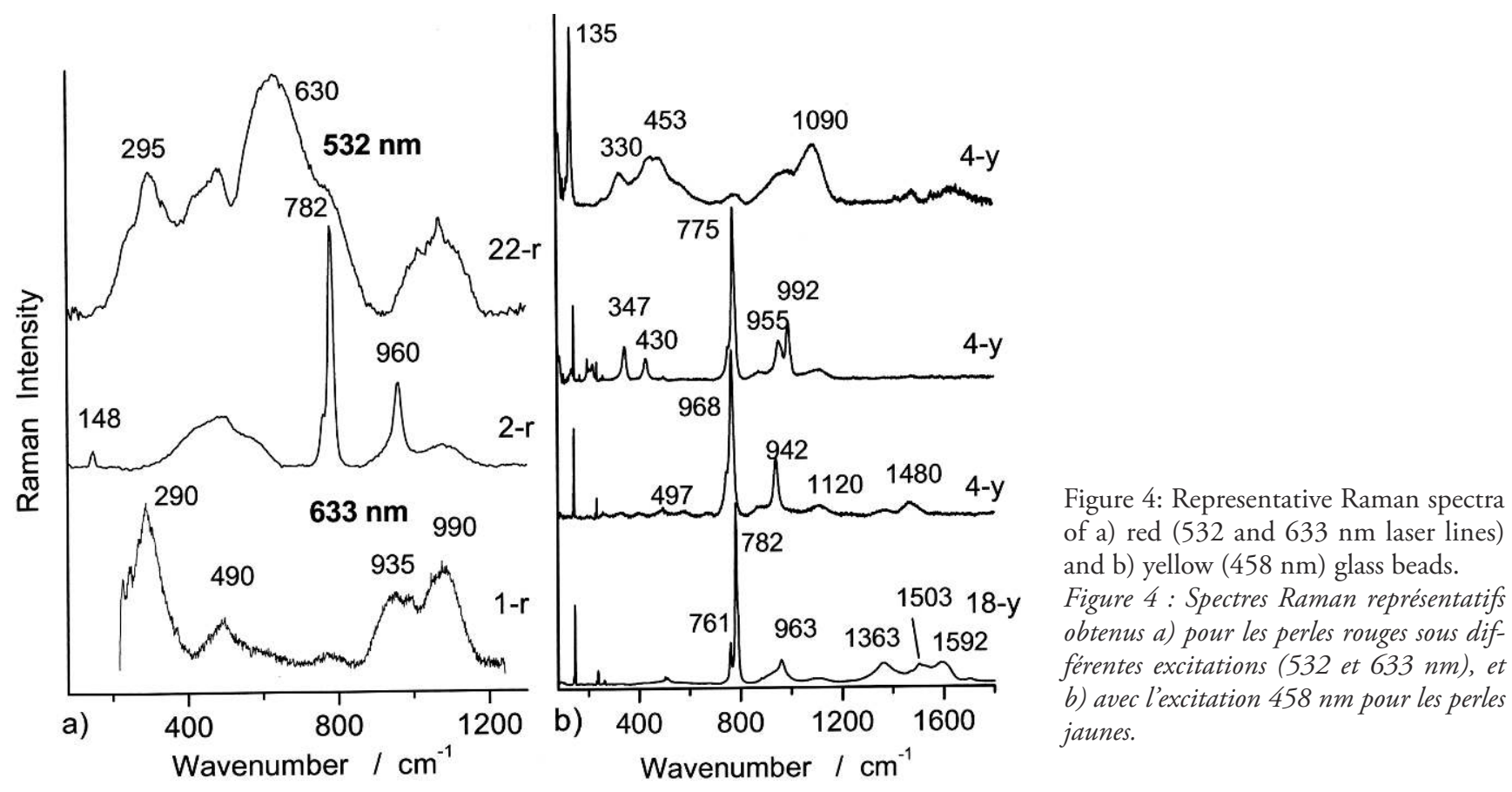

oxide), and iron (0.3-0.8\% by weight of oxide). The $\mathrm{Fe}^{2+}$ ion gives a light blue colour whereas the $\mathrm{Cu}^{2+}$ ion is the classic turquoise chromophore of alkaline glasses and enamels (Colomban \& Schreiber, 2005). The Cr-Sn chromophore is detected in bead 19-b (Figure 3).

\section{Black Beads}

Representative Raman spectra of black beads are given in Figure 5. For almost all of the analyzed beads, the identified black pigment corresponds to the amber chromophore "Fe-S" used to produce amber glass (Schreurs and Brill, 1984; Prinsloo \& Colomban, 2008). The resonant Raman spectrum of this pigment is characterized by a broad band around $415 \mathrm{~cm}^{-1}$, which is superimposed on the spectrum of the glass. The position of this band and its components depends on the glass matrix, i.e. the direct environment of the $\mathrm{Fe}-\mathrm{S}$ chromophore (Figure $5 \mathrm{a}$ ) and of the laser line used (Figure 5b). In Figure 5b, examples of the Raman signatures of bead 21-n obtained with different excitation wavelengths are given. Depending on the wavelength of the laser, the intensity and position of the main Raman band of the chromophore Fe-S vary (Prinsloo \& Colomban, 2008): the main peak at $413 \mathrm{~cm}^{-1}$ under green excitation $(532 \mathrm{~nm})$ moves to $390 \mathrm{~cm}^{-1}$ under red excitation (633 and $785 \mathrm{~nm}$ ), and loses intensity (Prinsloo and Colomban, 2008; Prinsloo et al., 2011). The spectrum recorded with the $785 \mathrm{~nm}$ laser line allows access to the Raman signature of the bead's vitreous matrix $\left(\mathrm{SiO}_{4} v_{\max }=1071 \mathrm{~cm}^{-1}, \mathrm{SiO}_{4} \delta_{\max }=482 \mathrm{~cm}^{-1}\right.$, Fig 5b, spectrum 21-n at $785 \mathrm{~nm}$ ).

Another black pigment has been detected in bead 13-n (Figure 5a), which corresponds to a manganese oxide characterized by the bands at 297, 480 and $633 \mathrm{~cm}^{-1}$ (Julien et al., 2004) and confirmed by SEM-EDS analysis (1.8 wt $\%$ of $\mathrm{MnO}_{2}$ ). A similar spectrum and a high Mn content was observed in Magoro black beads (Koleini et al., 2014; Koleini et al., 2016c). Precise identification of the oxide remains difficult, because of the high sensitivity of these (black) oxides to laser heating, as heating changing the degree of oxidation and allotrope. As with some yellow and red beads, the spectrum of $\mathrm{Cr}-\mathrm{Sn}$ chromophore was identified in some spots of the black beads 13-n and 21-n. Analyses by SEM-EDS clearly illustrate chromium (0.02-0.2 $\mathrm{wt} \%)$ and tin (0.09-0.1 wt $\%)$.

\section{White beads}

The Raman spectra of white beads (e.g. figure 6a) are typical of aragonite, an allotrope of calcium carbonate $\left(\mathrm{CaCO}_{3}\right)$ occurring in living matter, which exhibit characteristic peaks at 153, 208, 709 and $1084 \mathrm{~cm}^{-1}$ (White, 2008).

\section{Other Phases}

Figure $6 \mathrm{~b}$ presents the characteristic spectra of secondary crystalline phases encountered in glass matrices. The Raman spectrum 4-y, with peaks at 357, 440 and $1008 \mathrm{~cm}^{-1}$ is cha- 
Figure 5: Representative Raman spectra of the black beads a) with $532 \mathrm{~nm}$ excitation and according to the excitation wavelength for the black bead 21-n.

Figure 5 : Spectres Raman représentatifs obtenus a) pour différentes perles noires sous $532 \mathrm{~nm}$ et b) pour la perles noire 21-n sous différentes excitations laser.
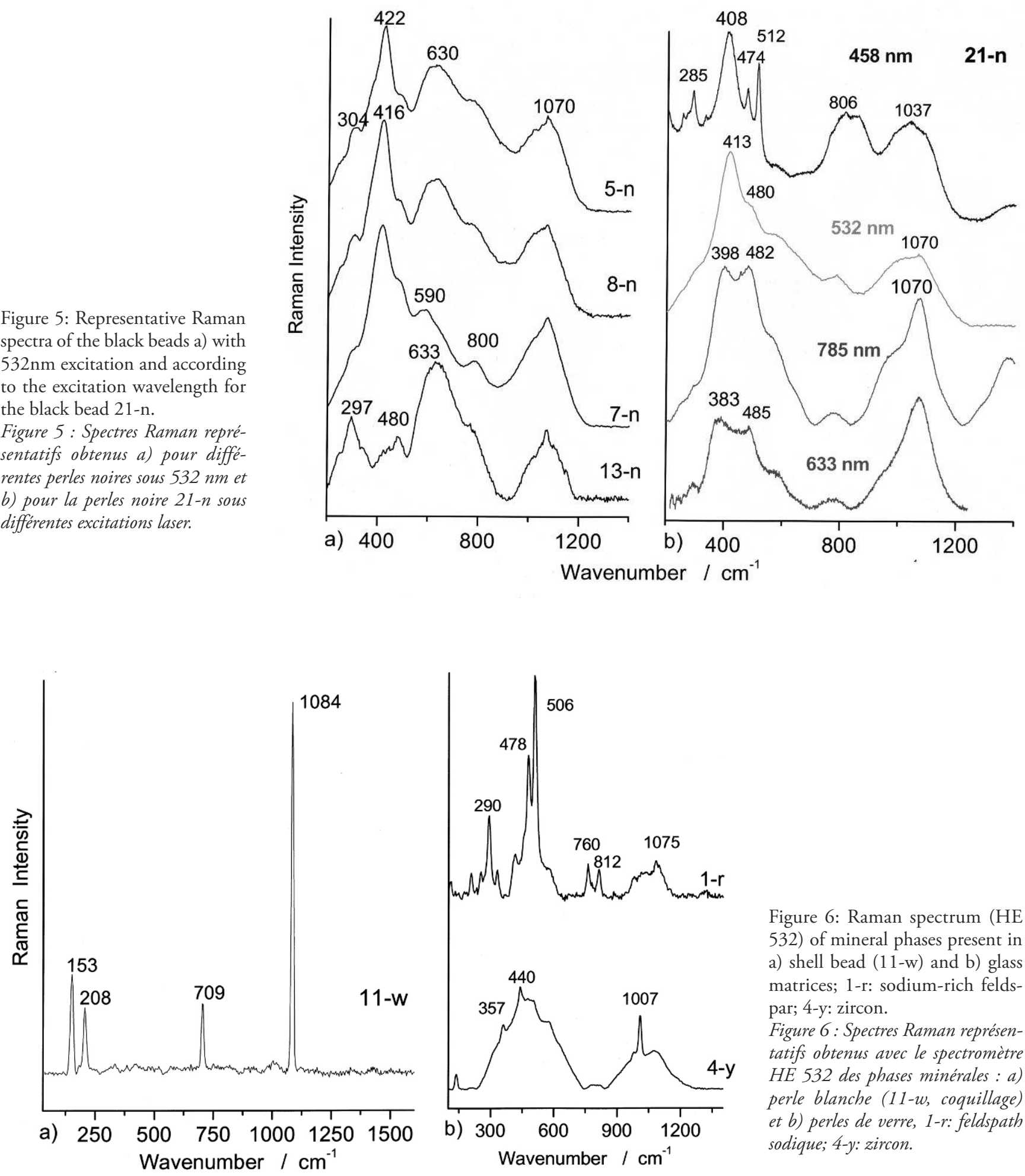

Figure 6: Raman spectrum (HE 532) of mineral phases present in a) shell bead (11-w) and b) glass matrices; 1-r: sodium-rich feldspar; 4-y: zircon.

Figure 6: Spectres Raman représentatifs obtenus avec le spectromètre HE 532 des phases minérales : a) perle blanche (11-w, coquillage) et b) perles de verre, 1-r: feldspath sodique; 4-y: zircon. 
racteristic of zircon, $\mathrm{ZrSiO}_{4}$ (Raskovska et al., 2010). This mineral, a very stable nesosilicate, detected in the beads $4-y$, $13-\mathrm{n}$ and $21-\mathrm{n}$ is present in many ancient rocks and products of their degradation (clays).

The Raman spectrum 1-r (290, 478, 506, 760 and $\left.812 \mathrm{~cm}^{-1}\right)$ is characteristic of a sodium-rich feldspar, albite $\mathrm{NaAlSi}_{3} \mathrm{O}_{8}$ (Freeman et al., 2008). It was identified in the beads $1-\mathrm{r}$ and $21-\mathrm{n}$. The feldspars are commonly used as fluxes in the glass or ceramic production. All characteristic peak wavenumbers are summarized in Table 4.

\section{Glassy matrix}

The micro-Raman spectrometry of amorphous silicate phases has already been subjected of numerous studies for non-destructive identification of glass or enamelled objects (Colomban et al., 2003; Colomban et al., 2006a; Colomban \& Treppoz, 2001; McMillan \& Piriou, 1982 and references herein). The glass is a more or less polymerized $\mathrm{SiO}_{4}$ network, with each tetrahedron sharing or not their oxygen ion. Ions lowering the melting point (mainly $\mathrm{Na}^{+}, \mathrm{K}^{+}, \mathrm{Pb}^{2+}$ and $\mathrm{Ca}^{2+}$ ) and the colouring ions are housed in the void spaces of the polymer network.

The Raman spectrum of an amorphous silicate is composed of two wide bands resulting from vibrations of the $\mathrm{SiO}_{4}$ tetrahedron, a strong covalent entity and vibrationally well defined: in the middle frequencies the band centred around $500 \mathrm{~cm}^{-1}$ corresponds to the symmetrical deformation vibrations $\left(\mathrm{\delta} \mathrm{SiO}_{4}\right)$; the second band around 1000 $\mathrm{cm}^{-1}$ corresponds to the symmetric stretching vibrations of the tetrahedron $\left(v \mathrm{SiO}_{4}\right)$. Actually, the contribution of asymmetric stretching and bending modes can be neglected (Colomban \& Prinsloo, 2009). The graphical representation of $v \mathrm{SiO}_{4}$ vs. $\delta \mathrm{SiO}_{4}$ maximum wavenumber distinguishes types of glass (Figure 7) (Caggiani et al., 2014; Colomban et al., 2005b; Colomban et al., 2006a). It is noted that an increase in alumina (i.e. the network ionicity) or lead (i.e. the depolymerization) in the glass composition causes major
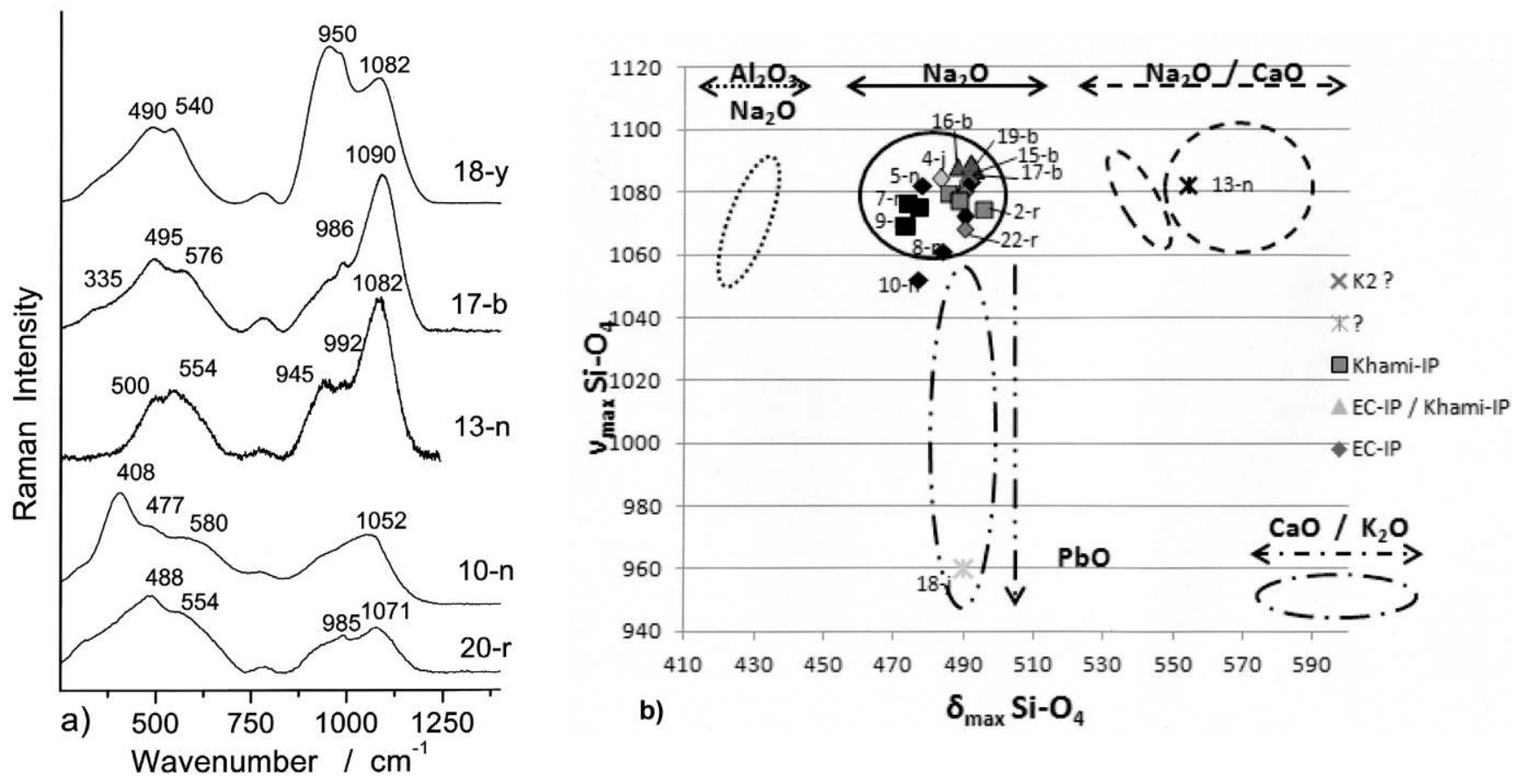

Figure 7: (See colour plate X) a) representative Raman spectra of the main glass matrix: 18-y) depolymerized glass; 17-b) soda glass with a high alumina content $\left.\left(\mathrm{Al}_{2} \mathrm{O}_{3} \mathrm{Na}_{2} \mathrm{O}\right) ; 10-\mathrm{n}\right)$ soda glass; $\left.20-\mathrm{r}\right)$ soda corroded glass. b) Classification of glassy matrices of the beads according to the maximum position of the Raman stretching $\left(v_{\max } \mathrm{Si}_{-} \mathrm{O}_{4}\right)$ as a function of the maximum deformation position $\left(\delta_{\max } \text { Si-O }\right)_{4}$. The areas delineated as typical of eras and backgrounds glass (see Figure 8). The colour of the beads and the specificities of each field are indicated. Symbols markers correspond to the classification of Wood.

Figure 7: (Voir planche couleur X) a) Spectres Raman représentatifs des matrices vitreuses: 18-y) verre dépolymérisé; 17-b) verre sodique riche en alumine (noté $\mathrm{Al}_{2} \mathrm{O}_{3} \mathrm{Na}_{2} \mathrm{O}$ ); 10-n) verre sodique; 20-r) verre sodique corrodé. b) Classification des matrices vitreuses à partir des positions des maxima du massif Raman des modes d'élongation $\left(v_{\max } S_{i-O_{4}}\right)$ et de déformation $\left(\delta_{\text {max }} S_{i-O_{4}}\right)$. Les zones des principaux types de verre sont indiquées (cf. Figure 8). Les couleurs et les principales caractéristiques sont notées. Les symboles correspondent à la classification morphologique de Wood. 
wavenumber shift (Colomban et al., 2006b; Tournié et al., 2008). Corrosion phenomenon with the protonation/leaching may also be responsible for lowering the bending and stretching mode wavenumber (Tournié et al., 2008).

Consistent with the results of the elemental analysis (Figure 7, Table 3), almost all beads are made of soda glass. $\mathrm{Na}_{2} \mathrm{O}$ content ranges between $12 \%$ and $18 \%$, except for beads \#7 (11.8\%) and \#9 (9.8\%). $\mathrm{K}_{2} \mathrm{O}$ content ranges between $1.5 \%$ and $2.8 \%$, except for black beads \#7, 10 and 21 exhibiting lower values (1.2\%-1.4\%). Only a spectrum corresponds to a more highly depolymerized glass (18-y, corrosion pits are visible in Figure 1) and a bead belongs to the soda-lime-type (13-n, stained with manganese oxide). The wound bead $10-n$ is located outside the dispersing zone of other soda beads in accordance with its particular process. The deformation band maximum $\left(\delta_{\max } \mathrm{SiO}_{4}\right.$ at 470 $\left.500 \mathrm{~cm}^{-1}\right)$ and the elongation band maximum $\left(v_{\max } \mathrm{SiO}_{4}\right.$, around 1080 to $1090 \mathrm{~cm}^{-1}$ ) are typical of a sodium silicate glass rather rich in $\mathrm{Al}_{2} \mathrm{O}_{3}$. The 17-b spectrum (Figure 7a) is typical of a highly polymerized soda glass, with three bands at 335,495 and $576 \mathrm{~cm}^{-1}$ and two very intense stretching components in $1090 \mathrm{~cm}^{-1}$ and another of medium intensity at $990 \mathrm{~cm}^{-1}$. The spectrum 13-n of soda-lime type is characterized by a band at $554 \mathrm{~cm}^{-1}$, and three stretching components at 945, 992 and $1082 \mathrm{~cm}^{-1}$. The data is somewhat scattered but it is possible to identify subgroups. The dispersion of structural changes is due to compositional variations, linked to variable raw materials used, or to the implementation of technology (purification / selection of raw materials). The beads "specificity" in terms of composition of the glass matrix is also found in terms of chromophore (13-n and 18 -y) or manufacturing technique (10-n).

The examination of the Raman profiles brings a number of additional information. In Figure 7a, the representative Raman signatures of the main glass matrices, demonstrate that in spite of their belonging to the same group (17-b, 10-n and 20-r) differences are visible. The 20-r spectrum is characteristic of a corroded glass. This alteration is attributed to a chemical reaction between the glass surface and an acidic aqueous solution causing the exchange of $\mathrm{K}^{+}$and $\mathrm{Na}^{+}$ $/ \mathrm{Mg}^{2+}$ ions by protonic species: moving the $v_{\max } \mathrm{SiO}_{4}$, to a lower wave number $\left(1072 \mathrm{~cm}^{-1}\right)$ corresponds to an elongation of the Si-O bond due to the interaction of oxygen atoms with the protonic species (Tournié et al., 2008).

The analysis by SEM-EDS was performed to complete the classification obtained by Raman spectroscopy, and identify chromophores which do not give specific Raman signatures. Most beads have a relatively high content of $\mathrm{Al}_{2} \mathrm{O}_{3}$ (6 to $9.5 \mathrm{wt} \%$, Table 3, in agreement with the original IndoPacific beads (Dussubieux et al, 2010; Robertshaw et al.,
2010), reflecting the use of a flux of mineral type. These compositions are shown graphically in ternary diagrams (Figure 8). The ternary diagram $\left(\mathrm{SiO}_{2}-\mathrm{Al}_{2} \mathrm{O}_{3}-\Sigma\right.$ fluxes $)$ in the Figure 8a \& a', is sensitive to both raw materials but also to technology because of the direct correlation between the amount of fluxes and of the operation temperature. This is to distinguish four sub-groups:

- A large majority of beads from Antsirak Boira consists of a flux-rich glass $(-20 \mathrm{wt} \%)$.

- Some black beads have clear inclusions and / or corrosion of red dots (9-n, 7-n, $21 n$ ), and the blue bead 16-b contains less flux $(-15 \mathrm{wt} \%)$.

- Bead 17-b appears isolated, with a very alumina-rich glass $\left(\mathrm{Al}_{2} \mathrm{O}_{3}-13 \mathrm{wt} \%\right)$.

- Beads 13-n and 15-b are richer in fluxes than all the other beads $(-23 \mathrm{wt} \%)$. The main difference of this black bead with those recovered from South-African Magoro Hill site is its higher $\mathrm{Al}$ and less $\mathrm{Mn}$ content.

The ternary diagram of fluxes $\left(\mathrm{Na}_{2} \mathrm{O}-\mathrm{CaO}-\mathrm{K}_{2} \mathrm{O}\right.$, Figure $8 \mathrm{~b}$ $\&$ b') refines the visualization of differences. The homogeneity of a glass notably depends on the temperature and heating time, the agitat ion of the melt, etc. Although all of the beads seem to be composed of a soda glass (Figure 7b), two sub-groups are emerging:

- The first consists of a glass matrix rich in sodium, which brings together the red beads (1-r, 2 r, 14 r, 20-r and 22-r) and a large majority of black beads (5-n, 6-n, 7-n, 8-n, 10-n, 12-n, 21-n).

- The second group consists of beads made of a glass richer in calcium (3-y, 9-n, 13-n, 17-b).

The comparison with literature data, presented in the ternary diagram of "Flux" (Figure 8 a' \& b'), confirms the beads of this assemblage belonging to the group of "IndoPacific" soda glass beads.

\section{Discussion}

We will highlight the identified characteristics of each family of bead, those features that are useful in the discussion of origins and dating. Table 4 lists the elements identified, pigments or dyes, and highlights the specific characteristics.

\section{Yellow beads}

Raman spectroscopy demonstrates for yellow beads 3-y and 4-y (Figure 3c) the use of a pyrochlore solid solution based on $\mathrm{Pb}_{2} \mathrm{Sb}_{2-\mathrm{x}} \mathrm{Sn}_{\mathrm{x}} \mathrm{Z}_{\mathrm{y}} \mathrm{O}_{7-\delta}$ solid solution, also called Naples Yellow (Colomban et al., 2001, Kirmizi et al., 2010, Perreira et al., 2009; Rosi et al., 2009). The presence of lead is confir- 

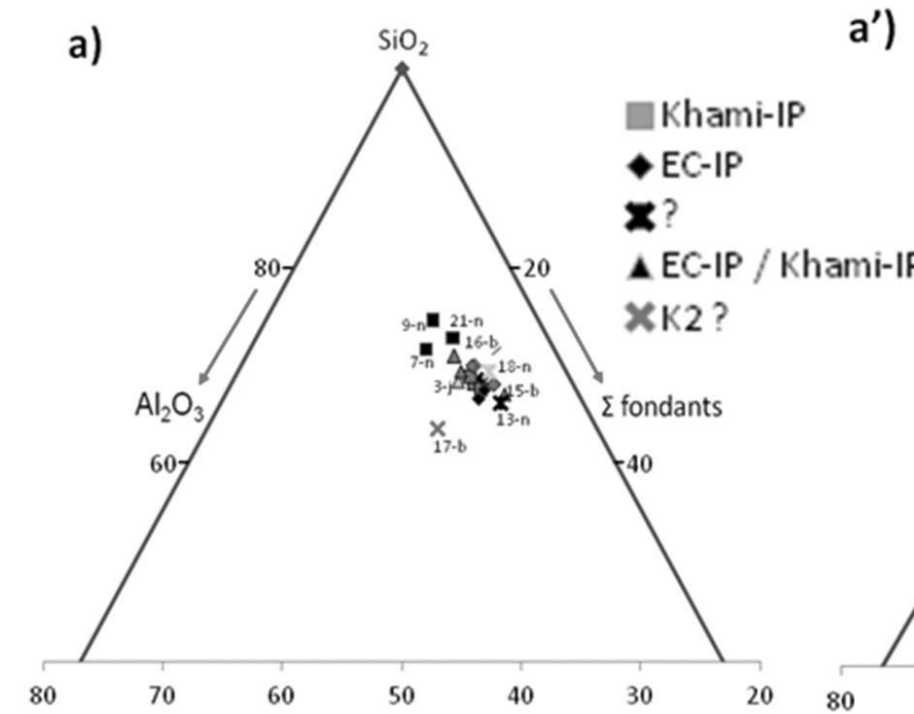

a')
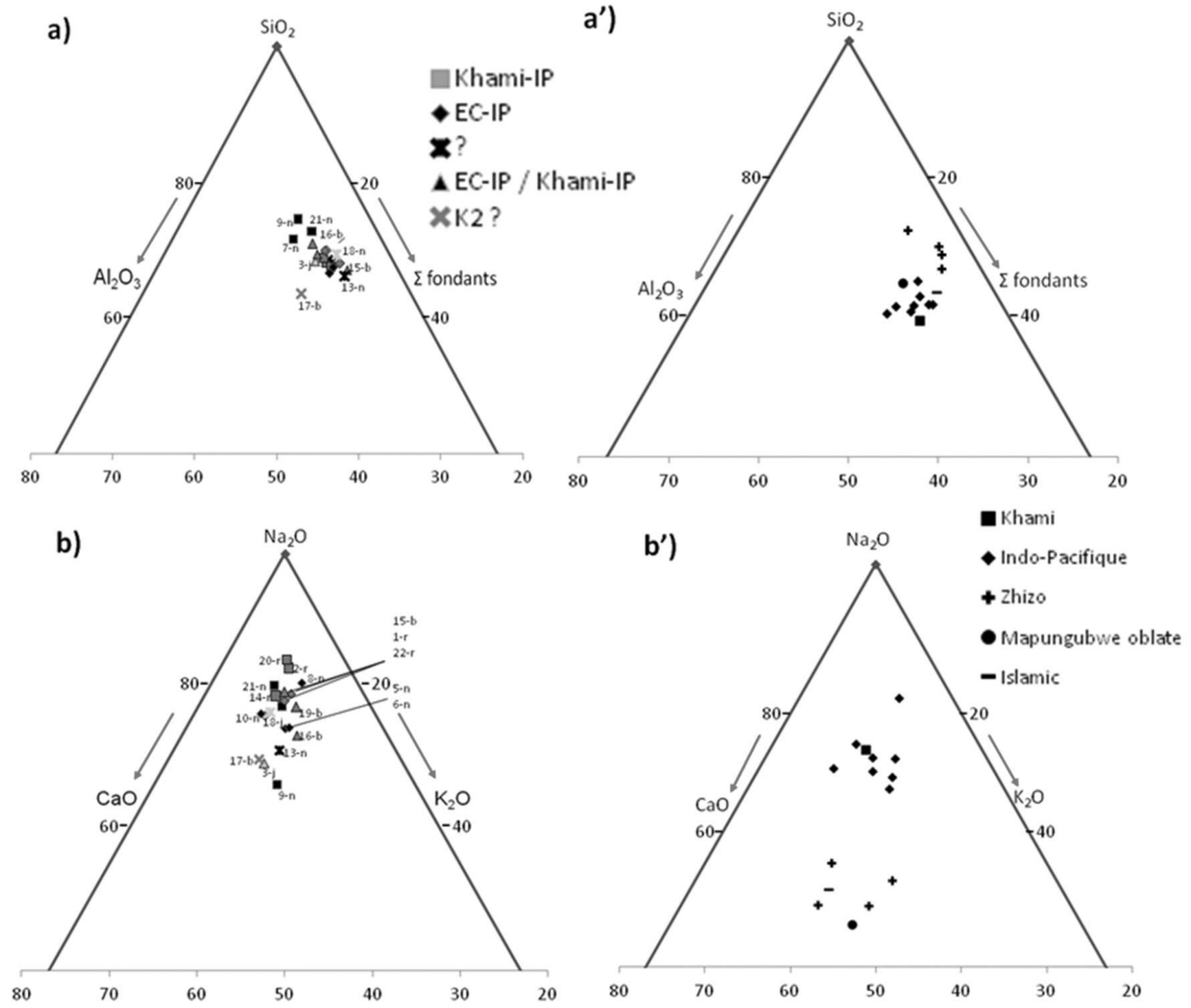

Figure 8: (See colour plate XI) Ternary composition diagrams for glass beads $\left(\mathrm{SiO}_{2}-\mathrm{Al}_{2} \mathrm{O}_{3}-\Sigma\right.$ fluxes) and $\left(\mathrm{Na}_{2} \mathrm{O}-\mathrm{CaO}-\mathrm{K}_{2} \mathrm{O}\right)$, normalized to 100 (see Table 2) - a) and b) are related to the composition of Mayotte beads. The colour of markers depends on the beads: a') and b') illustrate the literature data (Denbow et al, 2015; Dussubieux et al., 2008; Prinsloo and Colomban, 2008; Robertshaw et al., 2009, 2010; Welter et al., 2007).

Figure 8: (Voir planche couleur XI) Diagrammes en composition oxyde normalisée des perles pour les éléments majeurs ( $\mathrm{SiO}_{2}-\mathrm{Al}_{2} \mathrm{O}_{3}-\mathrm{\Sigma}$ fondants) et les fondants ( $\mathrm{Na}_{2} \mathrm{O}-\mathrm{CaO}-\mathrm{K}_{2} \mathrm{O}$, cf. Table 2) : a) \& b) perles de Mayotte (les couleurs des symboles correspondent aux couleurs des perles); a') \& b) données représentatives de la littérature (Denbow et al., 2015; Dussubieux et al., 2008; Prinsloo and Colomban, 2008; Robertshaw et al., 2009, 2010; Welter et al., 2007).

med by elemental analysis ( 0.1 to $0.2 \%$ by weight) with the exception of the 18-y bead which is colored by an iron yellow $(\sim 1.8 \mathrm{wt} \%)$ whose orange tone is due to the presence of the chromophore Cr-Sn, identified by Raman scattering. The elemental analysis showed the presence of tin traces $(\mathrm{Sn}$
$0.05 \mathrm{wt} \%)$. Naples Yellow solid solutions have been used in the Mediterranean area and Mesopotamia since Antiquity (Colomban, 2013) but the presence of Cr-Sn chromophore was not reported in the previous Raman studies. 


\begin{tabular}{|c|c|c|c|c|c|c|}
\hline $\begin{array}{l}\text { Pigments / } \\
\text { Coloring agents / } \\
\text { Phases crystalline }\end{array}$ & Bead color & Phases & $\begin{array}{c}\text { Raman peak } \\
\mathrm{cm}^{-1}\end{array}$ & Chromo-phore & $\begin{array}{l}\text { Period } \\
\text { Origin }\end{array}$ & Reference \\
\hline $\begin{array}{l}\text { Pyrochlore } \\
\text { Solid } \\
\text { solution }\end{array}$ & Yellow & $\mathrm{Pb}_{2} \mathrm{Sb}_{2-\mathrm{x}} \mathrm{Sn}_{\mathrm{x}} \mathrm{O}$ & $137-144$ & $\mathrm{~Pb}$ & $\begin{array}{c}\text { 1293-1570 av. } \\
\text { J.-C. } \\
\text { MO / IP }\end{array}$ & $\begin{array}{l}\text { Kirmizi et al., } \\
2009\end{array}$ \\
\hline Amber & Black & $\begin{array}{c}\text { Chromophore } \\
\text { Fe-S }\end{array}$ & $415-420$ & Fe. S & $\mathrm{I}-\mathrm{P}$ & $\begin{array}{c}\text { Prinsloo et } \\
\text { Colomban, } 2008\end{array}$ \\
\hline $\begin{array}{l}\text { Albite (Na-felds- } \\
\text { par) }\end{array}$ & $\begin{array}{c}\text { Black } \\
\text { Red-brun }\end{array}$ & $\mathrm{NaAlSi}_{3} \mathrm{O}_{8}$ & 290.478 .506 & & & $\begin{array}{l}\text { Freeman et al., } \\
2008\end{array}$ \\
\hline Copper & $\begin{array}{l}\text { Blue } \\
\text { Red }\end{array}$ & $\begin{array}{l}\mathrm{Cu}^{2+} \\
\mathrm{Cu}^{0}\end{array}$ & no & $\mathrm{Cu}$ & $\begin{array}{c}\text { Europe. MO } \\
\text { IP }\end{array}$ & $\begin{array}{c}\text { Colomban et } \\
\text { Schreiber, } 2005\end{array}$ \\
\hline Pyrolusite & $\begin{array}{c}\text { Red } \\
\text { Black }\end{array}$ & $\beta-\mathrm{MnO}_{2}$ & 280.490 .630 & $\mathrm{Mn}$ & & Julien et al., 2004 \\
\hline Iron ions & $\begin{array}{l}\text { Blue } \\
\text { Yellow }\end{array}$ & $\begin{array}{l}\mathrm{Fe}^{2+} \\
\mathrm{Fe}^{3+}\end{array}$ & no & $\mathrm{Fe}$ & IP & Colomban, 2004 \\
\hline $\begin{array}{c}\text { Sphene } \\
\text { (+anastase) }\end{array}$ & $\begin{array}{l}\text { Black } \\
\text { Red } \\
\text { Yellow }\end{array}$ & $\begin{array}{l}\text { Chromophore } \\
\text { Sphène } \mathrm{Sn} \\
\left(+\mathrm{TiO}_{2)}\right.\end{array}$ & 147.780 & $\begin{array}{l}\text { Ti. Sn } \\
(<0.2 \%)\end{array}$ & & Faurel et al., 2003 \\
\hline $\begin{array}{l}\text { Calcium phos- } \\
\text { phate }\end{array}$ & $\begin{array}{l}\text { Black } \\
\text { Red } \\
\text { Yellow }\end{array}$ & $\mathrm{P}-\mathrm{O}$ & $950-960$ & l & MO & $\begin{array}{l}\text { Ricciardi et al., } \\
\text { 2009b }\end{array}$ \\
\hline Zircon & $\begin{array}{l}\text { Black } \\
\text { Yellow }\end{array}$ & $\mathrm{ZrSiO}_{4}$ & 358.440 .1008 & $\mathrm{Zr}(21-\mathrm{n})$ & & $\begin{array}{l}\text { Tournié et al., } \\
2009\end{array}$ \\
\hline Aragonite & shell & $\mathrm{CaCO}_{3}$ & $\begin{array}{c}155.207 .704 . \\
1085\end{array}$ & & & White S.C., 2008 \\
\hline
\end{tabular}

Table 4: Raman fingerprints of pigments, chromophores and crystalline phases were in Mayotte beads. (IP: Indo-Pacific. MO: Middle East).

Tableau 4: Principaux pics Raman des pigments ou chromophores et des phases cristallines. (IP: Indo-Pacific. MO: Middle East).

\section{Red beads}

The element identified in red-brown beads is the metallic copper nanoparticles. The $\mathrm{Cu}$ content varies from 0.05 to $0.2 \mathrm{wt} \%$. In agreement with this type of coloring agent, Raman spectra of the glass matrix are very variable and difficult to obtain, as expected for glasses containing metallic nanoparticles (Colomban \& Schreiber, 2005). Since the Neolithic, the red color of the lead-based glasses is achieved in Europe by the dispersion of copper nanoparticles $\left(\mathrm{Cu}^{0}\right)$ in the glass matrix (Colomban et al., 2009) in a reducing environment. This practice has been widely used in the Roman period (Ricciardi et al., 2009a) and in some Islamic productions. Production in China was also suspected (Beaujard, 2012). The joint observation of Cr-Sn chromophore is also a very special feature of the studied glass.

\section{Blue and turquoise beads}

No blue pigment $\left(\mathrm{Co}_{2} \mathrm{SiO}_{4}, \mathrm{CoAl}_{2} \mathrm{O}_{4}\right.$, Lapis lazuli) was detected with Raman spectroscopy. The lack of the above mentioned signature is consistent with the color obtains by a small amount of cobalt dissolved in its ionic form in the glass. Elemental analyzes by SEM-EDS show a very low cobalt content, $\sim 0.01 \mathrm{wt} \%$ for the bead $16-\mathrm{b}$, in agreement with the light blue colour of the bead (less than $0.5 \mathrm{wt} \%$ of cobalt is sufficient to give an intense blue colour). The turquoise color (beads 15-b, 17-b \& 19-b) is the classical result of the dissolution of $\mathrm{Cu}^{2+}$ ions in an alkaline silicate glass matrix (Colomban \& Schreiber, 2005). Elemental analyses indicate $\mathrm{Cu}$ content between 0.1 and $0.3 \mathrm{wt} \%$. Iron detected by elemental analysis, is probably an impurity with no significant role in the color of matrix. So no specific markers for these beads were found, except the Cr-Sn chromophore present in the bead 19-b. 


\section{Black Beads}

The main identified coloring agent by Raman scattering in black beads, is the "Fe-S" amber chromophore. In parallel with the morphological and chemical classifications, the presence of "Fe-S" chromophore is in agreement with black "Indo-Pacific" beads, which are supposed to originate from the south of India, Sri Lanka or South-East Asia (Dussubieux et al., 2008; Prinsloo \& Colomban, 2008; Prinsloo et al., 2011). Accordingly, beads with variations in the position and intensity of the main Raman bands (Figure 5a) may indicate various origins or periods/production qualities.

The 13-n seems morphologically consistent with IndoPacific series. Nevertheless, and contrary to the morphological criteria, the lack of "Fe-S" chromophore shows another technology in production of this bead. It is possible these beads are related to a specific Indo-Pacific sub-group. A manganese oxide pigment is also observed in red, yellow and black beads (Figures $4 \mathrm{a}$ and $4 \mathrm{~b}$, Table 4). Cr-Sn sphene is also observed.

\section{White beads}

The white beads are made of aragonite, the allotrope of most limestone shells or corals. Visually similar beads were found on the African coastal sites, Tanzania (the ruins of Kaole) (Wood, 2012) and at Chibuene, south of the Mozambique Channel (Wood, 2012). Other aragonite beads were also identified at Mahilaka and Sandrakatsy, Madagascar, two sites dated between the $9^{\text {th }}$ and $15^{\text {th }}$ century A.D. (Robertshaw et al., 2006). Shells of Tridacna maxima were found as offerings in burials on Antsiraka Boira. The inorganic compound of this shell is aragonite (Romaneck et al., 1987). Since it is the most abundant species found in the archaeological levels around Acoua, these beads may well be locally manufactured, although no contemporary Mayotte site show traces of this production. In contrast, bead polishers were found on the Lamu Archipelago's Kenyan sites (Horton, 1996; Pauly, 2014) demonstrating this type of local production. These beads could thus be of African origin.

\section{Glass matrices}

Subgroups that were identified by Raman analysis coincide well with those identified by the ternary composition diagrams (Figure 8a \& b), but dispersions within each groups is different. Indeed, the structure of the network of $\mathrm{SiO}_{4}$ tetrahedron forming the glass skeleton is not only a function of composition, but also depends on other factors (temperature, manufacturing process etc.). Therefore, the same material composition may not have the same structure and vice versa. Furthermore, the SEM-EDS analysis made with different magnifications shows a significant differences in the local composition.

Soda glass is the constituent of all Indo-Pacific beads (type K2, East-Coast or Khami) dated according to Wood between the $10^{\text {th }}$ and the $17^{\text {th }}$ century (Robertshaw et al., 2010; Wood, 2005; Wood, 2011; Wood et al., 2009). The dispersion within the $\mathrm{Na}_{2} \mathrm{O}$ group may result in variations between compositions $\mathrm{K} 2$ groups, EC-IP and Khami due to the variability of raw materials but also of the surface alterations of some beads. So the red beads (1-r, 2-r, 14-r, 20-r and 22-r) belong to the soda group but the majority of Raman spectra are typical of a slightly corroded glass (whatever the elimination of surface film by grinding). The easy oxidation of metallic copper used for colouring (Colomban \& Schreiber, 2005; Ricciardi et al., 2009a) may be the source of significant corrosion for these red beads. The bead 17-b, outside of the main soda group presents a characteristic Raman signature similar to that of the K2 series (Prinsloo et al., 2011; Koleini et al., 2016a; Koleini et al., 2016c). The use of soda glasses is common in Southeast Asia/China ( $16^{\text {th }}$ century enamels), Venice and Holland ( $16^{\text {th }}$ and $17^{\text {th }}$ century A.D.) (Ricciardi et al., 2009b; Robertshaw et al., 2010; Dussubieux et al., 2010; Kirmizi et al., 2010; Colomban et al., 2006; Tournié, 2009; Prinsloo et al., 2011; Tournié et al., 2011) and this criterion alone does not qualify objects.

The presence of albite is consistent with a poor refining of molten glass (albite, chalk and silicates form liquid phase below $900^{\circ} \mathrm{C}$ ), and zircon a geological marker of raw materials. These minerals were detected in opaque beads, redbrown or black, which could then be categorized as very heterogeneous beads, closer to a molten ceramic. The same result was also obtained for some reddish beads of the Vohemar necropolis dated from $12^{\text {th }}-17^{\text {th }}$ century, north of Madagascar (Colomban \& Simsek, 2014). SEM imaging supports this hypothesis for the red and black cut beads, also revealing a highly porous matrix typical of unrefined molten material (Fischbach, 2015).

\section{Origin/production time}

Table 5 and Figure 9 summarize the characteristics of the different Antsiraka Boira beads according to Raman signature. The first observation compared to the results for the South African sites is the homogeneity of the corpus from the Antsiraka Boira necropolis. 


\begin{tabular}{|c|c|c|c|c|c|c|c|}
\hline \multirow{2}{*}{$\begin{array}{c}\text { Similar Raman } \\
\text { spectra } \\
(89)\end{array}$} & \multirow{2}{*}{$\begin{array}{c}\text { Selected } \\
\text { beads } \\
(22)\end{array}$} & \multirow{2}{*}{$\begin{array}{c}\text { Pigment / Chromophore/ } \\
\text { Phase }\end{array}$} & \multicolumn{4}{|c|}{ Glass matrix } & \multirow[b]{2}{*}{ Origin / Period } \\
\hline & & & $\mathrm{Na}_{2} \mathrm{O}$ & $\begin{array}{c}\mathrm{Na}_{2} \mathrm{O} / \\
\mathrm{CaO}\end{array}$ & $\mathrm{PbO}$ & $\begin{array}{c}\text { Corro- } \\
\text { ded }\end{array}$ & \\
\hline 5 & $1^{\mathrm{a}}$ & $\mathrm{Fe}^{3+}$ ion yellow / corrosion & & & $\mathrm{x}$ & $\mathrm{x}$ & ? \\
\hline 6 & $2^{\mathrm{b}}$ & Pyrochlore & $\mathrm{x}$ & & & & $\begin{array}{c}\text { Middle East / Indo-Pacific / } \\
\text { Europe }\end{array}$ \\
\hline 13 & $5^{c}$ & $\mathrm{Cu}^{0}$ nanoparticles & $\mathrm{x}$ & & & $\mathrm{x}$ & Indo-Pacific / Islamic \\
\hline 26 & $4^{\mathrm{d}}$ & Turquoise $\left(\mathrm{Cu}^{2+}\right.$ ion $)$ & $\mathrm{x}$ & & & & Indo-Pacific \\
\hline 32 & $8^{\mathrm{e}}$ & Black/ «Fe-S» & $\mathrm{x}$ & & & & I Indo-Pacific \\
\hline 3 & 1 & Black / Mn oxyde & & $\mathrm{x}$ & & & Mapungubwe / Europe? \\
\hline 4 & 1 & White / Aragonite & & & & & East Africa \\
\hline
\end{tabular}

a : 18-j. corrosion (HR 532 et $458 \mathrm{~nm})+$ chromophore Cr-Sn $(458 \mathrm{~nm})-\mathrm{b}:$ including 4-j Cr-Sn (458 nm) + zircon (HR 532) - c : including Cr-Sn in 2-r et 22-r (HR 532) and feldspar in 1-r (HR 532) - d : including 19-b Cr-Sn (HR 532) - e : including zircon \&t Cr-Sn in 21-n \& 13-n (HR 532). feldspar in $21-\mathrm{n}(458 \mathrm{~nm})$.

Table 5: A summary on the classification and analysing results of Antsiraka Boira beads. Colouring agents and types of glass matrices are given. Possible origins of pearls on the basis of the identified colorants are indicated.

Tableau 5: Résumé des caractéristiques des perles d'Antsiraka Boira, en particulier les agents colorants et les types de matrice vitreuse. Les origines supposées sont indiquées.

Figure 9: Comparison of the distribution of the glass types for beads from Antsiraka Boira necropolis with those of Mapungubwe and K2 sites, depending on the maximum position wavenumber of the Raman stretching band $\left(v_{\text {max }} \mathrm{Si}_{-} \mathrm{O}_{4}\right)$ vs. the maximum position of the deformation band $\left(\delta_{\max } \mathrm{Si}_{-} \mathrm{O}_{4}\right)$ (Mapungubwe Hill \& K2 data according Tournié et al., 2012).

Figure 9: Comparaison de la distribution des types de matrices vitreuses pour les perles de la nécropole d'Antsiraka Boira avec celles des sites de Mapungubwe Hill et de K2 (Tournié et al., 2012) dans le diagramme établi à partir des maxima des modes Raman d'élongation $\left(\mathrm{v}_{\max } \mathrm{Si}-\mathrm{O}_{4}\right)$ et de déformation $\left(\mathrm{\delta}_{\max }\right.$ $\left.\mathrm{Si}_{-} \mathrm{O}_{4}\right)$.

The beads' compositional data for different sites in South Africa shows a good correlation between Raman signatures and compositions (Figure 8a' \& b'). The classification of Antsiraka Boira beads on the basis of Wood morphological classification system appears almost correct. The beads of Indo-Pacific series (East Coast-IP, K2- IP, Khami-IP),

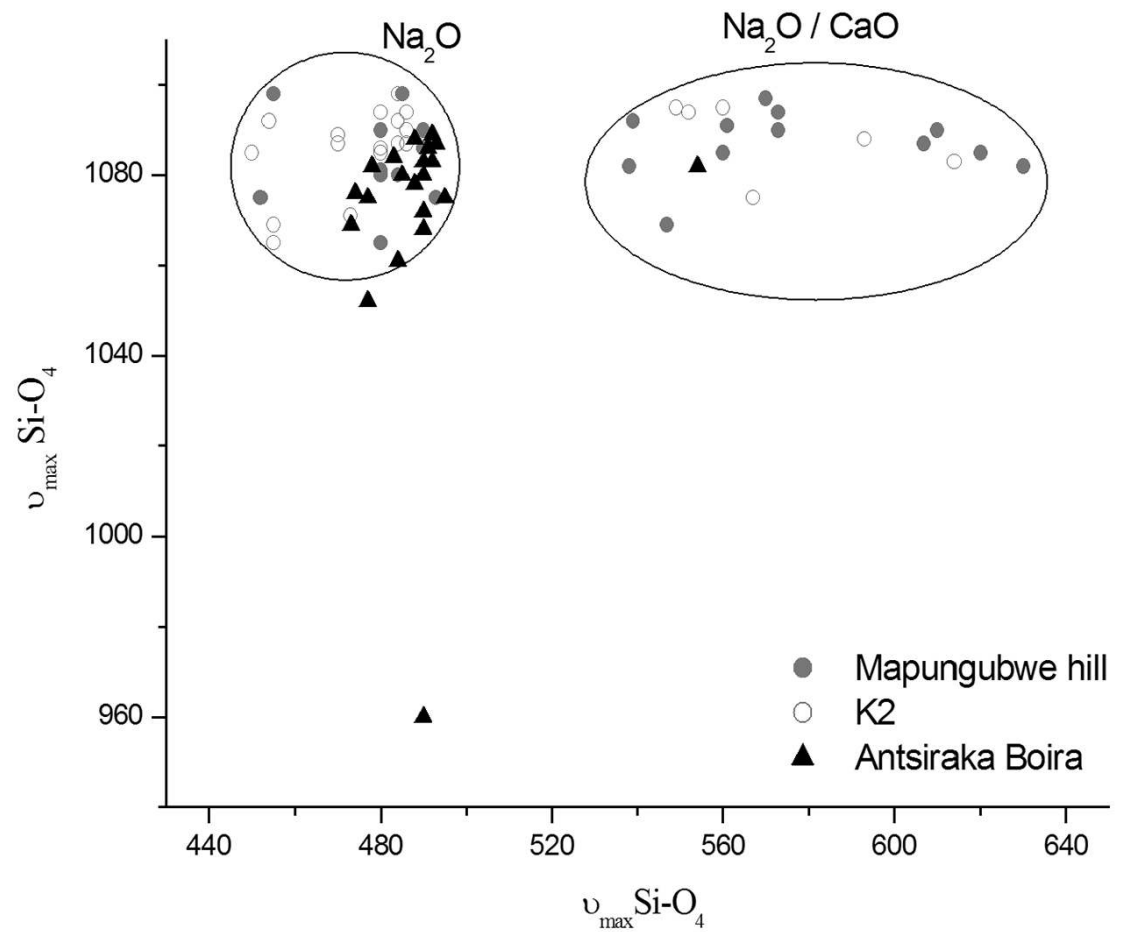

Mapungubwe Oblate and Islamic (South Africa), have a composition richer in $\mathrm{Al}_{2} \mathrm{O}_{3}$ than beads of Zhizo series. The series of Islamic, Mapungubwe Oblate and Zhizo have a high $\mathrm{CaO}$ content in comparison with Indo-Pacific beads. Dispersal areas of South Africa beads on the diagrams of Figures 7 and 8 belonging to the Indo-Pacific and Khami 
series match those beads of Antsiraka Boira, supporting the first conclusion of the Wood's morphological classification (Figure 1). However, there are compositional variations within the series (Figure 8, compatible with an inherent inhomogeneous quality of a non-industrial production), and allocating a bead to a specific series on the basis of its morphological features or its composition alone is not always clear cut, especially for Indo-Pacific series. The Cr-Sn sphene Raman signature (Table 6) in many beads offers a tool to identify this subgroup of Indo-Pacific production.

\section{A comparison with the beads of Mapungubwe and $\mathrm{K} 2$ sites}

Figure 9 compares the distribution of many beads' glass matrices from the Mapungubwe and K2 sites - two twin sites in the upper valley of the Limpopo River near the present meeting point of South Africa, Botswana and Zimbabwe (Prinsloo et al., 2011). The diagram constructed on the Raman parameters in analysing the structure of the polymeric network of $\mathrm{SiO}_{4}$ tetrahedron. Almost all of the beads from the Antsiraka Boira and $\mathrm{K} 2$ sites are soda $\left(\mathrm{Na}_{2} \mathrm{O}\right)$, while a significant portion of Mapungubwe beads belong to soda-lime group $\left(\mathrm{Na}_{2} \mathrm{O} / \mathrm{CaO}\right)$.

A wider dispersion was recorded between $\mathrm{Na}_{2} \mathrm{O}$ and $\mathrm{Na}_{2} \mathrm{O} / \mathrm{CaO}$ groups for Mapungubwe beads, while most of $\mathrm{K} 2$ beads belong to the $\mathrm{Na}_{2} \mathrm{O}$ group. The variety in glass structure can be explained by a much longer occupation of Mapungubwe $\left(11^{\text {th }}-19^{\text {th }}\right.$ century), which could be in accordance with many supplies origins and multiple technologies used, compared to K2 site and its shorter period of occupation $\left(9^{\text {th }}-13^{\text {th }}\right.$ century). Mayotte is much comparable to the contemporary $\mathrm{K} 2$ site for both short period of occupation and a more uniform glass structure. Mapungubwe $\mathrm{Na}_{2} \mathrm{O}$ / $\mathrm{CaO}$ glass bead also have less consistency in composition than $\mathrm{Na}_{2} \mathrm{O}$ group which is in accordance with the various sources and technologies used. K2 and Antsiraka Boira beads also have not much variety in pigments than those reported for Mapungubwe beads (Prinsloo et al., 2011; Tournié et al., 2011).

\section{ConClusion}

The use of parameters extracted from the Raman signature of matrices, allowed classifying Antsiraka Boira glass artefacts into a main group of Indo-Pacific soda glass, similar to that of the contemporary site of K2 in South Africa. Elemental analyses with SEM EDS certified the Raman results. Differences in the morphology of the beads are however clear. The peculiarity lies in red and some of the black beads, which seem to be closer to a molten ceramic than to a glass, akin to some beads from the Vohemar necropolis in the north of Madagascar $\left(14^{\text {th }}\right.$ to $16^{\text {th }}$ century necropolis). The used coloring agents are generally conventional: copper red, "Naples Yellow" - a pyrochlore solid solution -, the amber/black Fe-S chromophore, and $\mathrm{Cu}^{2+}$ ions in the turquoise color. Unexpectedly in the study of these beads, resonance Raman spectroscopy has identified the presence of a $\mathrm{Cr}-\mathrm{Sn}$ sphene chromophore. This pigment has been detected in several different beads: yellow, black, red, and turquoise; the presence of chromium and tin elements being confirmed by SEM-EDS analysis. This Raman signature is a marker of the origin of these glasses. The chromophore was not used as a colouring agent.

The Indo-Pacific beads of the Antsiraka Boira necropolis open a long period of overlap with other sites to determine the location of production facilities. A comparative study is necessary, especially to investigate whether the Cr-Sn sphene chromophore is present.

Despite the lower spectral resolution of the portable device, and its strong complex background, most of the

\begin{tabular}{|c|c|c|c|c|c|}
\hline \multirow{2}{*}{$\begin{array}{c}\text { Bead label } \\
\text { Cr-Sn }\end{array}$} & \multirow{2}{*}{ Colour / Agent } & \multicolumn{3}{|c|}{ Glass matrix } & \multirow{2}{*}{ Wood' serie } \\
\cline { 3 - 5 } & & $\mathrm{Na}_{2} \mathrm{O}$ & $\mathrm{Na}_{2} \mathrm{O} / \mathrm{CaO}$ & Corrodée & \\
\hline $4-\mathrm{y}$ & Pyrochlore & $\mathrm{X}$ & & $\mathrm{X}$ & EC-IP \\
\hline $18-\mathrm{y}$ & Yellow & $\mathrm{X}$ & & $\mathrm{X}$ & Khami \\
\hline $2-\mathrm{r}$ & $\mathrm{Red} / \mathrm{Cu}^{0}$ & $\mathrm{X}$ & & & EC-IP \\
\hline $22-\mathrm{r}$ & $\mathrm{Red} / \mathrm{Cu}^{0}$ & $\mathrm{X}$ & & & EC-IP / Khami \\
\hline $19-\mathrm{b}$ & Turquoise/Cu ${ }^{2+}$ & $\mathrm{X}$ & & & $?$ \\
\hline $13-\mathrm{n}$ & $\mathrm{Black} / \mathrm{MnO}_{2}$ & & $\mathrm{X}$ & & Khami \\
\hline $21-\mathrm{n}$ & $\mathrm{Black} / « \mathrm{Fe}-\mathrm{S}_{»}$ & $\mathrm{X}$ & & & \\
\hline
\end{tabular}

Table 6: Beads selection having a sphene type phase related to a $\mathrm{Cr}-\mathrm{Sn}$ chromophore (colour: b. blue or turquoise; $n$. black; r. red; y. yellow).

Tableau 6: Perles où le chromophore Cr-Sn sphène a été observé (couleur: b. bleu ou turquoise; $n$. noir; r. rouge; y. jaune). 
measurements performed with the portable Raman spectrometer led to significant and usable Raman spectra (Table 4). For crystalline compounds such as pigments, the characteristic Raman bands are narrow, often intense, and easily detectable on the Raman spectrum (Figure 2, 3-y). Therefore, the spectra obtained with the portable device allow easy identification of almost all crystal phases. Regarding the glass matrices, portable Raman analysis of yellow and turquoise beads is more difficult but sufficient in numerous measures. However, for red and black beads the useful signal can be very small compared to the background, especially if fluorescence is superimposed. The latter is very common for porous archaeological samples due to the biological film's degradation at the oxide surface. In this case, laboratory fixed instruments are better suited because of their better accuracy and overall performance. Blue, violet or UV energy excitement eliminates the biofilm causing fluorescence very easily and in a few minutes of irradiation.

The use of mobile equipment that can be implemented on-site overcomes the technical and ethical constraints related to the subject, offering the possibility of direct and rapid, in situ identification, without having to move / export objects. Thus, expanding the areas of intervention and the amount of accessible objects, and resulting in the acquisition of richer and more representative data. However, these portable devices are less efficient due to the devices' miniaturization which leads to low resolution, continuous background... and may - by degrading the quality of data cause inappropriate conclusions.

\section{Acknowledgements}

The authors thank the Department of Cultural Affairs (Department of Cultural Affairs and Communication Prefecture of Mayotte), Director Clotilde Kasten and the Curator of Archaeology, Edouard Jacquot who authorized the release of beads collections for this study. Dr Thomas Calligaro (C2RMF, Paris) is kindly acknowledged for the Brill and BBS glass standards.

\section{Bibliography}

Beaujard Ph., 2009. Un seul système-monde avant le $16^{\mathrm{e}}$ siècle? L'océan Indien au cour de l'intégration de l'hémisphère afroeurasien. In Ph. Beaujard, L. Berger et P. Norel (dir.), Histoire globale, mondialisations et capitalisme, Paris, La DécouverteRecherches, 82-148.
Beaujard Ph., 2012. Les mondes de l'océan Indien. Vol. 1, De la formation de l'État au premier système monde afro-eurasien. Vol. 2, L'océan Indien, au cour des globalisations de l'Ancien Monde (7e-15e siècles), Paris, Armand Colin.

Baert K., Meulebroeck W., Wouters H., Ceglia A., Nys K., Thienpont H., Terryn H., 2011. Raman spectroscopy as a rapid screening method for ancient plain window glass, Journal of Raman Spectroscopy 42: 1055-1061.

Beck H.C., 1937. The beads of Mapungubwe District. In L. Fouché (dir.). Mapungubwe I, Cambridge University Press, Cambridge, 104-113.

Bonneau A., Moreau J.-F., Auger R., Hancock R.G.V., Émard B., 2013, Analyses physico-chimiques des perles de traite en verre de facture européenne : quelles instrumentations pour quels résultats. Archéologiques, 26: 109-132.

Caggiani M.C., Valotteau C., Colomban Ph., 2014. Inside the glassmaker technology: search of Raman criteria to discriminate between Emile Gallé and Philippe-Joseph Brocard enamels and pigments signatures. Journal of Raman Spectroscopy, 45: 456-464.

Chaisuwan B., 2011. Early Contacts between India and the Andaman Coast in Thailand from the Second Century BCE to Elevanth Century CE. In P.-Y. Manguin, A. Mani Geoff Wade (dir.), Early Interactions between South and Southeast Asia, Institute of Southeast Asian Studies, Singapore, 83-111.

Colomban Ph., 2008. On-site identification and dating of ancient glasses: a review of procedures and tools. Journal of Cultural Heritage, 9 (Suppl.): 55-60.

Colomban Ph., 2009. The Use of Metal Nanoparticles to Produce Yellow, Red and Iridescent Colour, from Bronze Age to Present Times in Lustre Pottery and Glass: Solid State Chemistry, Spectroscopy and Nanostructure. Journal of Nano Research, 8: 109-132.

Colomban Ph., 2013. The destructive/non-destructive identification of enamels, pottery, glass artifacts and associated pigments - A brief overview. Arts, 2: 77-110.

Colomban Ph., Treproz F., 2001. Identification and differentiation of ancient and modern European porcelains by Raman macro- and micro-spectroscopy. Journal of Raman Spectroscopy, 32: 93-102.

Colomban Ph., Prinsloo L.C., 2009. Optical spectroscopy of silicates and glasses. In Spectroscopic properties of inorganic and organometallic compounds: Techniques, Materials and Applications, volume 40, J. Yarwood, R. Douthwaite \& S. Duckett (dir.), RSC Publishing, London.

Colomban Ph., Schreiber H.D., 2005. Raman signature modification induced by copper nanoparticles in silicate glass. Journal of Raman Spectroscopy, 36: 884-890. 
Colomban Ph., Simsex G., 2014. New investigation on glass beads from the necropolis of Vohemar, Northern Madagascar, unpublished.

Colomban Ph., Sagon G., Faurel X., 2001. Differenciation of antique ceramics from the Raman spectre of their coloured glazes and paintings. Journal of Raman Spectroscopy, 32: 351360.

Colomban Ph., Quang Liem N., Sagon G., Xuan Tinh H., Ba HoÂNH T., 2003. Microstructure, composition and processing of $15^{\text {th }}$ century Vietnamese porcelains and celadons. Journal of Cultural Heritage, 4: 187-197.

Colomban Ph., Bellot-Gurlet L., Tournié A., 2006a. Raman identification of glassy silicates used in ceramics, glass and jewellery: a tentative differenciation guide. Journal of Raman Spectroscopy, 37: 841-852.

Colomban Ph., Etcheverry M.-P., Asquier M., Bounichou M., Tournié A., 2006b. Raman identification of ancient stained glasses and their degree of deterioration. Journal of Raman Spectroscopy, 37: 614-626.

Colomban Ph., Tournié A., Ricciardi P., 2009. Raman spectroscopy of copper nanoparticle-containing glass matrices: ancient red stained-glass windows. Journal of Raman Spectroscopy, 40: 1949-1955.

DAvidson C.C., 1972. Glass beads in African archaeology: results of neutron activation analysis, supplemented by results of $X$-ray fluorescence analysis. Ph.D. dissertation, University of California, Berkeley.

Davidson C.C., Clark J.D., 1974. Trade wind beads: an interim report of chemical studies. Azania, 9: 75-86.

De Ferri L., Bersani D., Colomban Ph., Lottici P.P., Simon G., Vezzalini G., 2012. Raman study of model glass with medieval compositions: artificial weathering and comparison with ancient samples. Journal of Raman Spectroscopy, 43: 18171823.

Denbow J., Klehm C., Dussubieux L., 2015. Indian Ocean trade into the far interior of Southern Africa. Antiquity, 89: 361-377.

Dussubieux L., Kusimba C.M., Gogte V., Kusimba S.B., Gratuze B., Oka R., 2008. The trading of ancient glass beads: new analytical data from South Asian and East African sodaalumina glass beads. Archaeometry, 50: 797-821.

Dussubieux L., Gratuze B., Blet-Lemarquand M., 2010. Mineral soda alumina glass: occurrence and meaning. Journal of Archaeological Science, 37: 1646-1655.

Eppler R.A., Eppler D.F., 2000 Glazes and Glass Coatings, The American Ceramic Society, Westerville.

Faurel X., Vanderperre A., Colomban Ph., 2003. Pink pigment optimization by resonance Raman spectroscopy. Journal of Raman Spectroscopy, 34: 290-294.
Fischвach N., 2015. Analyse de perles provenant de l'île de Mayotte. MSc dissertation, Université de Bordeaux.

Freeman J.J., Wang A., Kuebler K.E., Jolliff B.L., Haskin L.A., 2008. Characterization of natural feldspars by Raman spectroscopy for future planetary exploration. The Canadian Mineralogist, 46: 1477-1500.

Gardner G.A., 1963. Mapungubwe, II. J.L. van Schaik (dir.), Pretoria.

Gedzevieiute V., Welter N., Schüssler U., Weiss C., 2009. Chemical composition and colouring agents of Roman mosaic and millefiori glass, studied by electron microprobe analysis and Raman microspectroscopy. Archeoogical and Anthropological Sciences, 1: 15-29.

Henderson J., Chenery S., Kröger J., Faber E.W., 2016. Glass provenance along the Silk Road: The use of trace element analysis, ch. 2 in Recent advances in the scientific research on ancient glass and glaze. In F. Gan, Q. Li and J. Henderson (ed.), Series on Archaeology and History of Science in China, Vol. 2, World Scientific, Singapore, 17-42.

Horton M., 1996. Shanga, The archaeology of a Muslim trading community on the coast of East Africa, BIEA, Londres, 326-327.

Julien C.M., Massot M., Poinsignon C., 2004. Lattice vibrations of manganese oxydes Part I. Periodic structures. Spectrochimica Acta Part A, 60: 689-700.

Kirmizi B., Colomban Ph., Quette B., 2010. On-site analysis of Chinese Cloisonné enamels from fifteenth to nineteenth centuries. Journal of Raman Spectroscopy, 41: 780-790.

Koleini F., Prinsloo L., Colomban Ph., Boeyens J., van der Ryst M., Biemond W., 2014. A Raman Spectroscopic classification of glass trade beads recovered from Magoro Hill, an African farmer site located on age old Trade Route in Limpopo Province, South Africa. $14^{\text {th }}$ Congress on Pan-African Archaeologic Association, Johanesburg, 14-18 July 2014.

Koleini F., Prinsloo L.C., Biemond W.M., Colomban Ph., Nego A., Boeyens J., van der Ryst M., 2016a. Towards refining the classification of glass trade beads imported into southern Africa from the $8^{\text {th }}$ to the $16^{\text {th }}$ century A.D., Journal of Cultural Heritage: 19, 435-444.

Koleini F., Pikirayi I., Colomban Ph., 2016b. Revisiting Baranda: A multi-analytical approach in the classification of $16^{\text {th }} / 17^{\text {th }}$ century glass beads from Northern Zimbabwe, Antiquity, in press.

Koleini F., Prinsloo L.C., Biemond W., Colomban Ph., NGo A. T., Boeyens J., VAN Der Ryst M.M., 2016c. Glass trade on Magoro Hill, an archaeological site in southern Africa: glass types and pigments, Heritage Sciences, in press.

McMillan P., Piriou B., 1982. The structure and vibrational spectra of crystals and glasses in the silica-alumina system. Journal of Non-Crystalline Solids, 53: 279-98. 
Nativel O., Rajaonah F.V., 2007. Madagascar et l'Afrique. Entre identité insulaire et appartenances Historiques. Karthala, Paris, 105-108.

Pauly M., 2014. La diffusion de l'Islam à Mayotte à l'époque médiévale. Taärifa, 4: 63-89.

Pereira M., de Lacerda-Aroso T., Gomes M.J.M., Mata A., Alves L. C., Colomban Ph., 2009. Ancient Portuguese Ceramic Wall Tiles (“Azulejos”): Characterization of the Glaze and Ceramic Pigments. Journal of Nano Research, 8: 79-88.

Prinsloo L.C., Colomban Ph., 2008. A Raman spectroscopic study of the Mapungubwe oblates: glass trade beads excavated at an Iron Age archaeological site in South Africa. Journal of Raman Spectroscopy, 39: 79-90.

Prinsloo L.C., Tournié A., Colomban Ph., 2011. A Raman spectroscopic study of glass trade beads excavated at Mapungubwe hill and K2, two archaeological sites in southern Africa, raises questions about the last occupation date of the hill. Journal of Archaeological Science, 38: 3264-3277.

Prinsloo L.C., Boeyens Jan C.A., Van der Ryst M.M., Webb G., 2012. Raman signatures of the modern pigment (Zn,Cd) $\mathrm{S}_{1-\chi} \mathrm{Se}_{\chi}$ and glass matrix of a red bead from Magoro Hill, an archaeological site in Limpopo Province, South Africa, recalibrate the settlement chronology. Journal of Molecular Structure, 1023: 123-127.

Raskovska A., Minceva-Sukarova B., Grupce O., Colomban Ph., 2010. Characterization of pottery from Republic of Macedonia II. Raman and infrared analyses of glazed pottery finds from Skopsko Kale. Journal of Raman Spectroscopy, 41: 431-439.

Ricciardi P., Colomban Ph., Tournié A., Macchiarola M., Ayed N., 2009a. A non-invasive study of Roman Age mosaic glass tesserae by means of Raman spectroscopy. Journal of Archaeological Science, 36: 2551-2559.

Ricciardi P., Colomban Ph., Tournié A., Milande V., 2009 b. Nondestructive on-site of ancient glasses: genuine artefacts, embellished pieces or forgeries? Journal of Raman Spectroscopy, 40: 604-617.

Robertshaw P., Rasoarifetra B., Wood M., Melchiorre E., Popelka-Filcoff R.S., Glascock M.D., 2006. Chemical analysis of glass beads from Madagascar. Journal of African Archaeology, 4: 91-109.

Robertshaw P., Magnavita S., Wood M., Melchiorre E., Popelka-Filcoff R., Glascock M.D., 2009. Glass beads from Kissi (Burkina Faso): chemical analysis and archaeological interpretation. In S. Magnavita, L. Koté, P. Breunig, O. A. Idé (dir.), Crossroads: Cultural and technological developments, 1st millennium BC / AD West Africa. In Journal of African Archaeology Monograph Series (Frankfurt am Main: Africa Magna Verlag), 2: 105-118.
Robertshaw P., Wood M., Melchiorre E., Popelka-Filcoff R.S., Glascock M.D., 2010. Southern African glass beads: chemistry, glass sources and patterns of trade. Journal of Archaeological Science, 37: 1898-1912.

Romanek C.S., Jones D.S., Williams D.F., Krantz D.E., RADTKE R., 1987. Stable isotopic investigation of physiological and environmental changes recorded in shell carbonate from the giant clam Tridacna Maxima. Marine Biology, 94: 385-393.

Rosi F., Manuali V., Miliani C., Brunetti B. G., Sgamellotti A., Grygar T.,, Hradil D., 2009, Raman scattering features of lead pyroantimonate compounds. Part I: XRD and Raman characterization of $\mathrm{Pb}_{2} \mathrm{Sb}_{2} \mathrm{O}_{7}$ doped with tin and zinc, Journal of Raman Spectroscopy, 40: 107-11.

Sakellariou K., Miliani C., Morresi A., Ombelli M., 2004, Spectroscopic investigation of yellow majolica glazes, Journal of Raman Spectroscopy, 35: 61-7.

Schreurs J.W.H., Brill R.H., 1984, Iron and sulphur related color in ancient glasses, Archaeometry, 26: 199-209.

Schofield J.F., 1958. South Africa beads. In R. Summers (dir.), Inyanga. Cambridge University Press, Cambridge, 180-229.

Tournié A., 2009. Analyse Raman sur site de verres et vitraux anciens : modélisation, procédure, lixiviation et caractérisation. Thèse de doctorat, Université Pierre et Marie Curie, Paris 06.

Tournié A., Ricciardi P., Colomban Ph., 2008. Glass corrosion mechanisms: a multiscale analysis. Solid State Ionics, 179: 2142-2154.

Tournié A., Prinsloo L.C., Colomban Ph., 2010. Raman spectra database of the glass beads excavated on Mapungubwe Hill and K2, two archaeological sites in South Africa. University of Petroria. HAL, [https://hal.archives-ouvertes. fr/hal-00543867/ document] (access 03/06/2015).

Tournié A., Prinsloo L.C., Colomban Ph., 2011. Raman classification of glass beads excavated on Mapungubwe hill and K2, two archaeological sites in South Africa. Journal of Raman Spectroscopy, 43: 532-542.

Van Riet Lowe C., 1955. The glass beads of Mapungubwe. Archaeological Series, 9, Archaeological Survey, Union of South Africa.

Vicenzi E.P., Eggins S., Logan A., Wysoczanski R., 2002. Microbeam characterization of Corning archaeological references glasses. New additions to the Smithsonian microbeam standard collection, Journal of Research of the National Institute of Standard and Technology, 107: 719-727.

Welter N., Schülssler U., Kiefer W., 2007. Characterisation of inorganic pigments in ancient glass beads by means of Raman microspectroscopy, microprobe analysis and X-ray diffractometry. Journal of Raman Spectroscopy, 38: 113-121.

White S.N., 2008. Laser Raman spectroscopy as a technique for identification of seafloor hydrothermal and cold seep minerals. Chemical Geology, 39: 560-568.

ArCheoSCiences, revue d'archéométrie, 40, 2016, p. 83-102 
Wood M., 2005. Glass beads and Pre-European trade in the Shashe-Limpopo-region. MSc dissertation, University of the Witwatersrand, Johannesburg.

Wood M., 2011. A glass bead sequence for Southern Africa from the $8^{\text {th }}$ to the $16^{\text {th }}$ century AD. Journal of African Archaeology, 9: 67-84.
Wood M., 2012. Interconnections; Glass beads and trade in southern and eastern Africa and the Indian Ocean $-7^{\text {th }}$ to $16^{\text {th }}$ centuries AD. PhD dissertation, Uppsala University.

Wood M., Dussubieux L., Wadly L., 2009. A cache of -5000 beads from the sibudu cave Iron Age occupation. Southern African Humanities, 21: 239-261. 

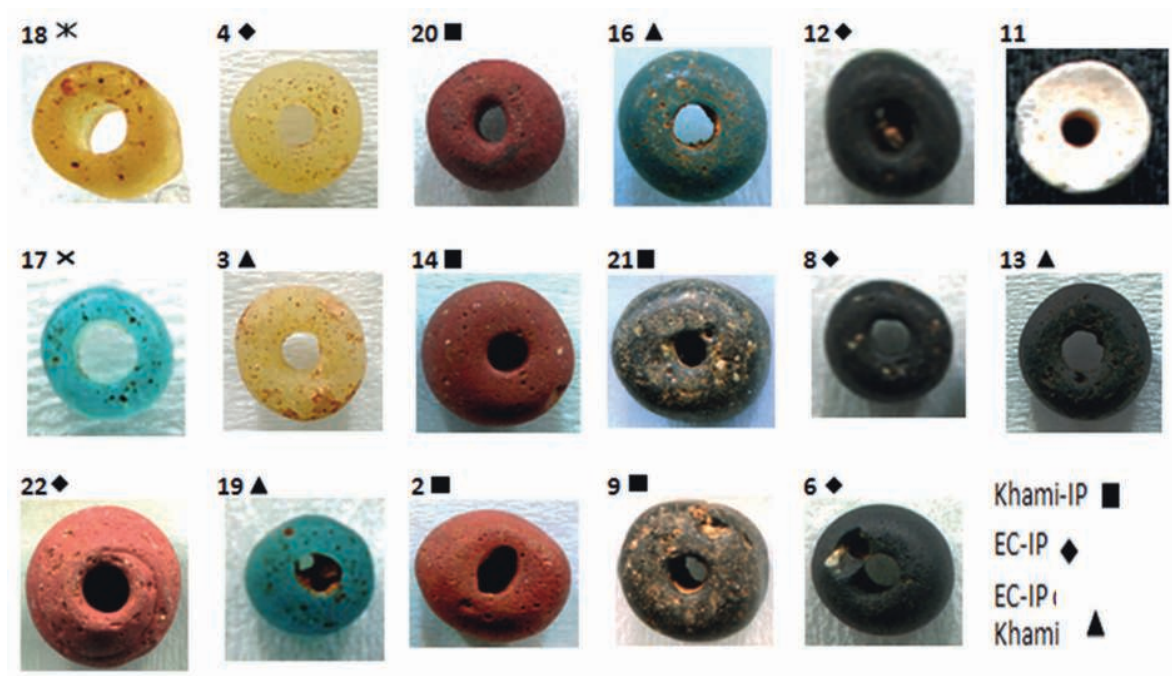

Khami-IP

EC-IP

EC-IP,

Khami
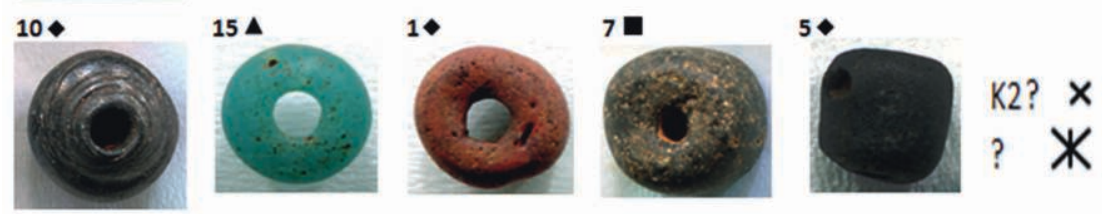

Figure 1 : Noémi FischBach et al., Beads Excavated from Antsiraka Boira Necropolis (Mayotte Island, $12^{\text {th }}-13^{\text {th }}$ centuries)Colouring Agents and Glass Matrix Composition Comparison with Contemporary Southern Africa Sites (p. 86)
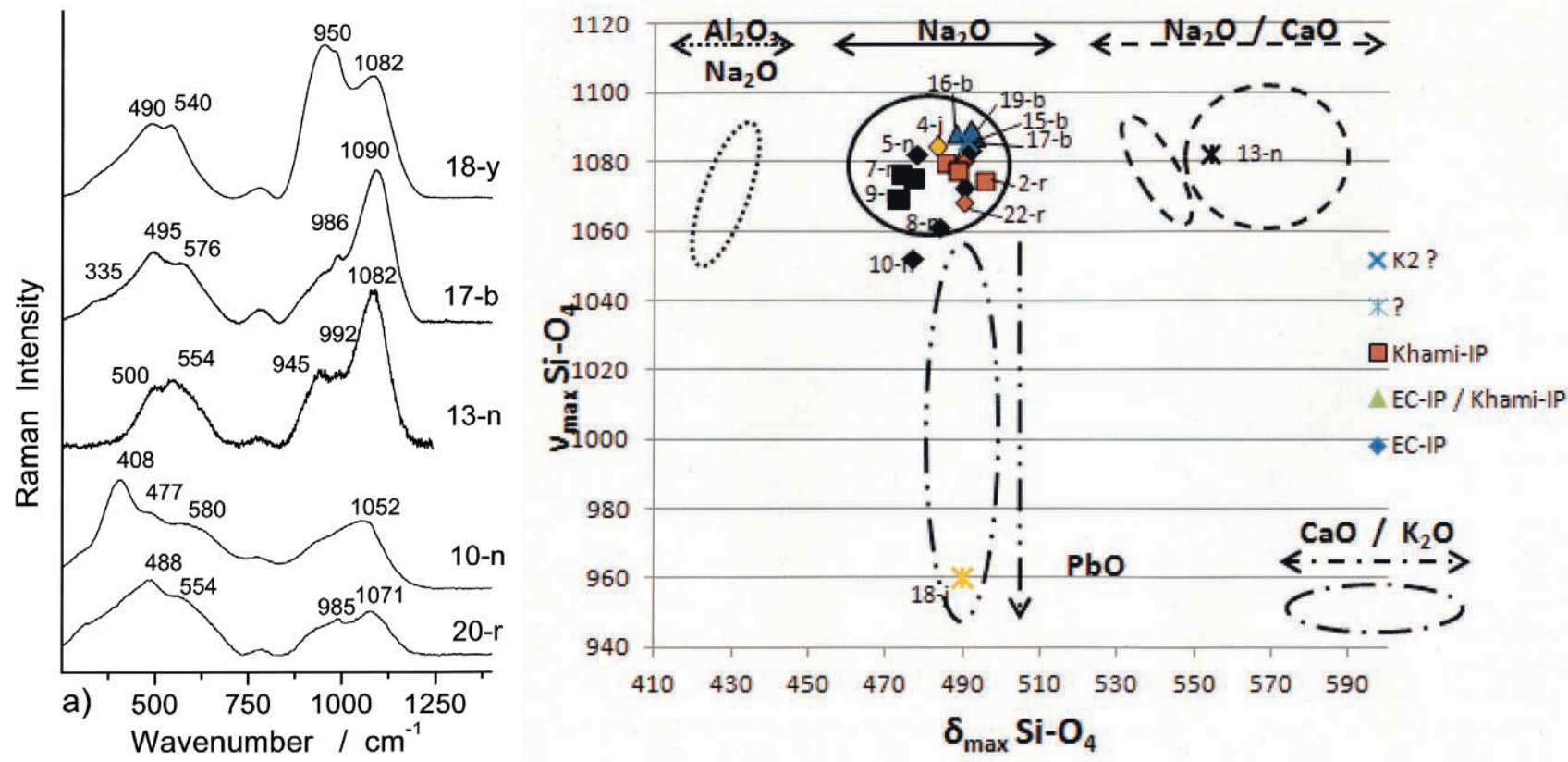

Figure 7 : Noémi FischBAch et al., Beads Excavated from Antsiraka Boira Necropolis (Mayotte Island, $12^{\text {th }}-13^{\text {th }}$ centuries)Colouring Agents and Glass Matrix Composition Comparison with Contemporary Southern Africa Sites (p. 92) 

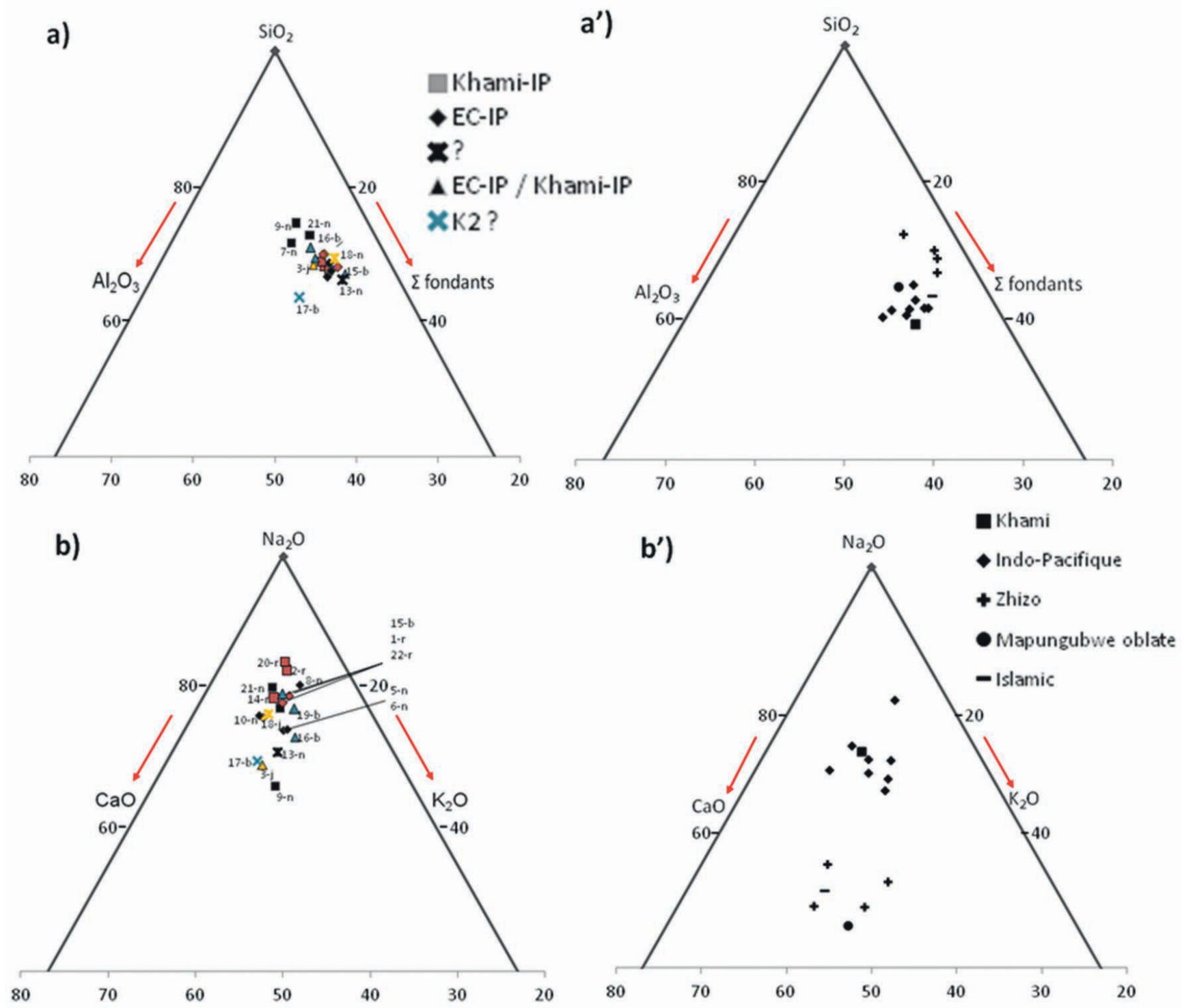

Figure 8 : Noémi Fischbach et al., Beads Excavated from Antsiraka Boira Necropolis (Mayotte Island, 12 $2^{\text {th }} 13^{\text {th }}$ centuries)Colouring Agents and Glass Matrix Composition Comparison with Contemporary Southern Africa Sites (p. 94) 